\title{
Illegal immigration and media exposure: evidence on individual attitudes
}

\author{
Giovanni Facchini 1,2,3,4,5,6,8, Anna Maria Mayda 3,5,6,7,8* (1) and Riccardo Puglisi, 6,9
}

*Correspondence:

amm223@georgetown.edu

${ }^{3}$ CEPR, London, UK

${ }^{5}$ CreAM, London, UK

Full list of author information is

available at the end of the article

\begin{abstract}
Illegal immigration has been the focus of much debate in receiving countries, but little is known about the drivers of individual attitudes towards illegal immigrants. To study this question, we use the CCES survey, which was carried out in 2006 in the USA. We find evidence that - in addition to standard labor market and welfare state considerations-media exposure is significantly correlated with public opinion on illegal immigration. Controlling for education, income, ideology, and other sociodemographic characteristics, individuals watching Fox News are 9 percentage points more likely than CBS viewers to oppose the legalization of undocumented immigrants. We find an effect of the same size and direction for CNN viewers, whereas individuals watching PBS are instead more likely to support legalization. Ideological self-selection into different news programs plays an important role, but cannot entirely explain the correlation between media exposure and attitudes about illegal immigration.
\end{abstract}

JEL Classification: F22, F1, J61

Keywords: Immigration, Illegal immigration, Attitudes, Preferences, Media

\section{Introduction}

Immigration is one of the most salient policy issues in the USA. Gallup polls conducted in May 2006 and May 2007 show that immigration was considered the second most important problem facing the country, with, respectively, 13 and $24 \%$ of respondents mentioning it. As the number of undocumented immigrants has increased (Passel 2005), much of the recent discussion has focused on illegal immigration. While a small literature is emerging which tries to measure the costs and benefits of illegal immigration (Hanson 2006), little is known on the factors that influence individual attitudes towards this facet of globalization. The purpose of this paper is to carry out what, to the best of our knowledge, is the first national-level systematic study of the determinants of public opinion on illegal immigration and, in particular, of the role played by the media in shaping these attitudes. $^{1}$

To undertake our analysis, we use the newly released Cooperative Congressional Election Study (CCES), ${ }^{2}$ an individual-level survey conducted immediately before and after the 2006 midterm elections. At that time, two legislative initiatives on illegal immigration were being considered in the US Congress. The bill discussed in the House (H.R. 4437) focused on border enforcement and deportation of illegal immigrants. The Senate proposal (S. 2611) contained instead a more complex set of initiatives. Besides calling

(c) The Author(s), 2017 Open Access This article is distributed under the terms of the Creative Commons Attribution 4.0 International License (http://creativecommons.org/licenses/by/4.0/), which permits unrestricted use, distribution, and reproduction in any medium, provided you give appropriate credit to the original author(s) and the source, provide a link to the Creative Commons license, and indicate if changes were made. 
for increased security, it expanded the number of guest workers and, importantly, it introduced a path to legalization for undocumented immigrants.

The CCES contains two questions which are particularly suited for the purpose of our study. The first one asks each respondent to state whether he/she would have voted for the Senate plan. The second one, which was asked only to a subsample of the population, directly compares the House and the Senate proposal. We use answers to these questions to assess the views of each respondent on illegal immigration. In analyzing the drivers of individual attitudes, we focus on the role played by the media, while controlling for the other standard economic and noneconomic drivers which have been highlighted in the literature. The CCES is unique for our purpose as, besides providing a wealth of information on the socio-economic characteristics of the respondents, it also contains information on the TV evening news program they most frequently watch (ABC World News, CBS Evening News, CNN, Fox News, PBS The NewsHour, NBC Nightly News, MSNBC, and others). To investigate the role played by the actual content of the newscast, we have supplemented this information with content coverage data obtained from the Dow Jones Factiva online archive.

To carry out our empirical analysis, we estimate a series of probit regressions. In our main specification, the dependent variable is a pro-Senate plan dummy, which is constructed from answers to the first policy question described above. Controlling for other economic and noneconomic drivers, we find that media exposure plays an important role in shaping public opinion on illegal immigration. According to our estimates, respondents watching Fox News are 9 percentage points more likely to oppose the lenient Senate plan (relative to CBS viewers). This result is broadly consistent with the findings of recent studies on the political position and the persuasive role of Fox News (Groseclose and Milyo 2005; DellaVigna and Kaplan 2007). Perhaps surprisingly, we find that CNN viewers entertain an attitude towards illegal immigration which is very similar to the one displayed by Fox News viewers. This result might be explained by a "Lou Dobbs" effect. ${ }^{3}$ Instead, the opposite effect holds for PBS viewers, who are 14 percentage points more likely, relative to CBS viewers, to support the Senate plan. It is important to notice that ideological self-selection into different news channels plays a relevant role, but does not completely explain the correlation between media exposure and policy attitudes on illegal immigration. In fact, when controlling for self-reported ideology and party identification, the estimated effect for Fox News and PBS is significantly smaller in absolute value than when not controlling for these variables but still large and highly significant. ${ }^{4}$ In addition, and most importantly, the estimated effect for $\mathrm{CNN}$ is larger in absolute value when controlling for self-reported ideology and party identification. This means that, in the case of $\mathrm{CNN}$, the impact of the news program works in the opposite direction with respect to self-selection, and thus, the coefficient on $\mathrm{CNN}$ is if anything biased towards zero due to self-selection. These results give us confidence that our correlations are at least in part driven by the causal impact of media exposure. In addition, we also find that the count of stories covering migration in a given evening news program has a negative and significant impact on the propensity to support the Senate plan: this result is also unlikely to be driven by self-selection since the number of stories covering migration should not be a decisive factor in the choice of the evening news program watched.

When forming their opinion about a certain issue, individuals are also influenced by the real-world events pertaining to that issue (Behr and Iyengar 1985). Our findings are 
consistent with this framework: controlling for media coverage and other confounding factors-e.g., the state-level fraction of legal immigrants-individuals living in states with a larger fraction of illegal immigrants are significantly more favorable to the Senate plan. The estimated correlation is quantitatively significant: an additional 1 percentage point in the fraction of illegal immigrants is associated with a 1 percentage point increase in the propensity to support the Senate plan.

We also find that economic drivers play an important role. In particular, individuals are more favorable to the Senate's "more lenient" plan if they are more skilled and richer. To better interpret these results, we also run the same regressions using-as the dependent variable-the dummy constructed from answers to the second policy question, which explicitly asks respondents to compare the Senate and the House plan. Our findings in the two sets of specifications are very similar. This suggests that-when answering the question about the Senate plan-respondents have in mind the House plan as the alternative.

Our result that more skilled individuals are more favorable to the Senate plan is in line with the existing literature on the drivers of attitudes towards overall migration. Compared to the House plan, the Senate plan increases the labor market competition faced by unskilled workers, both by being more lenient on deportations as well as by legalizing illegal workers, thus broadening their employability across sectors. Since illegal immigrants are mostly unskilled, both these effects increase the relative supply of unskilled labor. ${ }^{5}$ The positive impact of individual skill is then consistent with the existence of labor market complementarities between skilled and unskilled labor, which have been shown to be important drivers of attitudes by Scheve and Slaughter (2001), Mayda (2006), O’Rourke and Sinnott (2006), and Ortega and Polavieja (2012). ${ }^{6}$

Our findings suggest also that the welfare state plays an important role in shaping attitudes towards legalization as richer individuals are more likely to support the Senate plan. A plausible explanation of this result is that both poor and rich individuals feel penalized by the Senate plan through the welfare state channel-since they perceive legalization as worsening the position of public finances. However, the poor are more affected than the rich, because they expect benefits to fall, either in quantity or quality, and they use public services relatively more than the rich.

The remainder of the paper is structured as follows. In Section 2, we review the related literature, while in Section 3, we provide some background information about illegal immigration in the USA and the two legislative proposals discussed by the US Congress during 2006. In Section 4, we describe the data. The results of our statistical analysis are discussed in Section 5, while Section 6 is devoted to a series of robustness checks. Section 7 concludes.

\section{Related literature}

This paper is related to two strands of the literature. The first looks at the impact of the media on policy preferences, whereas the second considers the various drivers of individual attitudes towards immigration.

A vast body of literature, both in economics and political science, has studied how the media can shape policy preferences. In particular, political science and communication scholars have highlighted three main channels. First, several studies have focused on the agenda-setting power of the media, according to which the amount of coverage devoted 
to a particular issue can influence the importance readers and/or viewers attach to it (McCombs and Shaw 1972). ${ }^{7}$ Second, as noted by McCombs (2002), the media not only can make an issue more salient by increasing coverage but it can also emphasize particular attributes of the issue itself. The theory of priming thus describes how readers and viewers, when assessing a situation or individual, are pushed towards giving a larger weight to the aspect emphasized by the media. ${ }^{8}$ Similarly, framing refers to how the media can associate an issue to another, in order to affect an individual's perception. ${ }^{9}$

Turning to the economics literature, recent analyses-taking as given and known the ideological position of a media outlet-have tried to measure the media's persuasion effect by exploiting experimental or quasi-experimental settings on the degree to which individuals are exposed to that outlet. ${ }^{10}$ For instance, DellaVigna and Kaplan (2007) find that the gradual introduction of Fox News in cable markets has increased the Republican vote share in presidential elections between 1996 and 2000. Using an experimental setting, Gerber et al. (2008) do not find instead any significantly different effect of exposure to the Washington Times vs. the Washington Post on the Democratic vote in the 2005 Virginia gubernatorial elections. ${ }^{11}$

Moving from the general impact of the media to the impact on preferences-specifically on a given policy-exposure to different media sources might affect individual support by altering the balance between "considerations" that are favorable and/or unfavorable to that policy (Zaller 1992). As far as attitudes towards immigration are concerned, the agenda-setting power of the media can influence them through two different channels. First, individuals might hold views on the phenomenon, which are "activated" only when migration is made salient by media coverage. Second, the timing of the coverage might matter. An ideologically biased media could strategically devote more attention to migration only in the presence of "bad" events related to it, and disregard it in the presence of "good" events, to highlight the foreigners' negative impact on the community. ${ }^{12}$ Third, priming and framing choices by the media might exert a direct effect on attitudes. ${ }^{13} \mathrm{~A}$ media outlet can decide to systematically frame the immigration issue in a negative or positive fashion, thus affecting the point of view entertained by their audience and ultimately their feelings about the issue. This mechanism could work independently of the overall amount of coverage.

Two recent papers explicitly investigate the link between media exposure and migration attitudes. Abrajano and Singh (2009) focus on Spanish-speaking individuals in the USA and show-in a cross-sectional exercise-that those watching Spanish-language channels display more positive attitudes on migration than those watching English-language ones. De Philippis (2009) matches instead individual-level data from the European Social Survey with country-level data on media coverage of immigration from the Dow Jones Factiva. She finds that-controlling for economic and cultural drivers-individuals are significantly less favorable to immigration when media outlets in their country more frequently portray immigration within a controversial frame.

Besides media exposure, several studies have emphasized the role of other drivers of preferences towards immigration, both economic and noneconomic ones. Particular emphasis has been put on the importance of labor market competition and of the redistribution carried out by the welfare state in shaping preferences. Concerning the former, Scheve and Slaughter (2001) and Kessler (2001) find that, in the USA, more educated individuals are more likely to be pro-immigration, a result which is consistent with the 
evidence that immigrants to that country are on average less skilled than natives. ${ }^{14}$ Similar results have also been obtained by Mayda (2006) and O'Rourke and Sinnott (2006) for a set of developed and developing countries, using the variation in the relative skill distribution of migrants to natives across countries. Immigration-receiving countries are often characterized by large welfare states, and the impact of immigration on individual preferences through this channel has been studied by several papers. For instance, Hanson et al. (2007), Facchini and Mayda (2009), and Dustmann and Preston (2007) find strong evidence that welfare state considerations matter in shaping attitudes on overall immigration-using variation in the extent of redistribution carried out across US states as well as across advanced Western economies.

Immigration attitudes are also influenced by noneconomic, cultural factors. Hainmueller and Hiscox (2007) and Hainmueller and Hiscox (2010) have emphasized that more educated immigrants might be more pro-migration because they are more open towards different cultures, more cosmopolitan, and more tolerant, and not just because they fear less competition in the labor market from unskilled immigrants. Furthermore, as pointed out by Dustmann and Preston (2007), "differences" between the immigrant and the native population might induce a more negative appraisal of immigration, to the extent that natives fear a dilution of nation-specific characteristics and/or have a preference for cultural (and ethnic) homogeneity. In particular, the results for Great Britain obtained by Dustmann and Preston (2007) suggest that racist feelings have a particularly strong effect on attitudes towards overall migration. More generally, Card et al. (2012) consider the relative role of economic factors and "compositional amenities"-i.e., a broad class of externalities arising from the fact that people value the characteristics of their neighbors and co-workers, which are fundamentally changed by immigration. Importantly, they find that both dimensions play a significant role but that compositional amenities explain 3-5 times more of the individual variation in attitudes towards immigration.

Summing up, a substantial literature has investigated the drivers of public opinion on overall immigration. At the same time, little is known on what shapes attitudes towards illegal immigration, even though this phenomenon is at the forefront of the political debate. The purpose of this paper is to fill this gap, focusing on the role played by the media in shaping them.

\section{Illegal immigration in the USA}

Generally speaking, illegal immigration refers to labor movements across national borders taking place in a way that violates the immigration laws of the destination country. Assessing the number of illegal immigrants residing in the USA involves some educated guessing. It is well known that illegal aliens do respond to government surveys such as the Current Population Survey or the decennial Census. While the CPS and Census do not ask explicitly whether the foreign-born is legally or illegally present in the country, a wide range of research institutes and the Office of Immigration Statistics (OIS) within the Department of Homeland Security have constructed estimates of the number of illegal immigrants, for example, based on the socio-economic characteristics available in the CPS or Census data. The most common method to estimate the number of illegal immigrants is to take the difference between the measured immigrant population and the sum of past legal immigration flows. Estimates obtained using 
this methodology vary substantially, ${ }^{15}$ but as of January 2006, the OIS reports that there were 11.6 million unauthorized immigrants in the USA. Of these, 4.2 millions had entered in 2000 or later, and close to $60 \%$ of the total number of illegal immigrants was from Mexico.

The number of illegals has been steadily increasing from the early nineties until today. Many estimates suggest that, between 1995 and 2005, the inflows of unauthorized migrants-at over 700,000 per year-have actually been larger than those of legal arrivals (Passel 2005). Importantly, the distribution of illegals is highly concentrated. According to the OIS estimates, the ten states which were the largest recipients of undocumented immigrants accounted for approximately three quarters of the total, and California and Texas alone had more than four million illegal aliens in 2006. This is not surprising, as the two states share a border with Mexico, and at least since 1990, the vast majority of immigrants from that country are illegally living in the USA (Passel 2005).

To understand the impact of illegal immigrants on domestic residents, it is important to analyze the socio-economic characteristics of these individuals. Recent estimates by the Pew Hispanic Center (Passel 2005) suggest that the following stylized facts hold: (1) unauthorized immigrants are younger than both natives and legal immigrants; (2) they are substantially less educated than both natives and legal immigrants; (3) they work in lower wage occupations, and they earn substantially less than natives and legal migrants in the same occupations; (4) they are concentrated in a relatively small number of industries; ${ }^{16}$ (5) poverty rates among illegals are particularly high; and (6) well over $50 \%$ of illegal immigrants do not have health insurance.

As a response to the rapid increase in the number of illegal immigrants in the last 10 years, two important pieces of legislation have been introduced on the Congress floor between 2005 and 2006. "The Border Protection, Anti-terrorism, and Illegal Immigration Control Act" of 2005 (H.R. 4437, i.e., what we labeled the House plan in Section 1) was presented on June 12, 2005, by the Wisconsin Republican Congressman Jim Sensenbrenner. The legislation was passed by the US House of Representatives on December 16, 2005, by a vote of 239 to 182 (with 92\% of Republicans supporting it and $82 \%$ of Democrats opposing it), but it did not pass the Senate. Its main goal was to reduce illegal immigration flows, by introducing a series of measures ranging from the construction of 700 miles of reinforced fencing along the US-Mexico border to making it a crime to live in the USA illegally. The proposal was the catalyst of many immigrant rights protests, which culminated on April 10, 2006, when demonstrations against the bill and its provisions were carried out in 102 American cities.

The second bill, "The Comprehensive Immigration Reform Act" (CIRA, S. 2611, i.e., what we label the Senate plan in Section 1) was instead a US Senate bill introduced by Democrat Senator Arlen Specter of Pennsylvania on April 7, 2006. This bill took a more comprehensive approach to immigration reform and can be considered a compromise attempt after the failed introduction of the so-called Kennedy-McCain proposal of 2005 (S. 1033). Its main goal was also to increase security along the US southern border with Mexico, but it contained important additional provisions. In particular, it called for an expansion of the number of guest workers over and above those already present in the USA, through a new "blue card" visa program, and for allowing long-time illegal immigrants to gain legal status. This would have been the second major legalization initiative in 20 years, after the one included in the 1986 "Immigration Reform and Control Act." 
The bill was passed by the Senate on May 25, 2006, by a vote of 62-36. More details on both measures are reported in Table 1.

While neither bill became law because they failed to pass the conference committee, they have been important catalysts for the immigration debate of that period. Thus,

Table 1 Details about the bills passed by the Senate and the House (source: The New York Times)

\begin{tabular}{lll}
\hline & Bill passed by the Senate & Bill passed by the House \\
\hline Legalization of undocumented & Would give illegal immigrants who & No provisions for legalization, \\
immigrants & have lived in the USA for 2 years or & although a conservative leader in \\
& more a path to eventual citizenship. & the House, Representative Mike \\
& Illegal immigrants who have been & Pence, proposed a separate bill that \\
& here less than 2 years would be & would allow illegal immigrants to \\
& required to leave the country & become guest workers, but not \\
& altogether. They could apply for & permanent residents or citizens. \\
& the guest worker program, but they & \\
& would not be guaranteed & \\
& acceptance in it.
\end{tabular}

Temporary worker program

Number of guest workers to be admitted annually

Worksite enforcement

Criminal penalties for existing illegal immigrants

Border security: fencing

Border security: personnel
Creates a guest worker program with a path to legal permanent residence.
In December, the House defied President Bush's call for a guest worker program although the separate bill recently introduced by Mike Pence, the leader of the conservative caucus in the House, would allow illegal immigrants to become guest workers.

Negotiations in the Senate bill have reduced the number of foreign guest workers to be admitted annually to 200,000 a year from 320,000 .

The legislation would require employers to use an electronic employment verification system that would distinguish between legal and illegal workers.

Mandates penalties for smuggling aliens but offers exceptions for those who provide "humanitarian" assistance to immigrants, including medical care and housing. Also, illegal immigrants convicted of a felony or three misdemeanors would be deported.

The bill initially called for limited "double- or triple-layered fencing," but as the debate progressed, the Senate added provisions for 350 miles of border fencing and 500 miles of vehicle barriers between the USA and Mexico.

Increases the number of Border Patrol agents by 2,400 each year through 2011 to the current force of 11,300 agents.
No such provisions in the House bill.

Requires employers to participate in an electronic employment eligibility verification system within 3 to 6 years.

Makes it a federal crime to live in the USA illegally. Individuals who help illegal immigrants to enter or stay in the country would also face criminal penalties.

Requires the construction of "at least two layers of reinforced fencing" as well as "physical barriers, roads, lighting, cameras and sensors" along approximately 700 miles of the US-Mexico border.
Hires more Border Patrol agents "as expeditiously as possible." Nearly 12,000 Border Patrol agents currently stand guard. Hires at least 250 active duty port of entry inspectors for each of the next 3 years. 
understanding the drivers of individual views on these measures will provide us with valuable information on how illegal immigration is perceived.

\section{The data}

In this study, we use the 2006 round of the Cooperative Congressional Election Study (CCES), which was conducted by YouGov/Polimetrix of Palo Alto, California, and is the result of the joint effort of researchers in 30 US universities. The survey was carried out via the Internet and is based on a matched random sample, which has been constructed following a two-step procedure. First, a very large number of people-over 150,000 individuals - were recruited to participate in the online survey. Second, a random sample was drawn from the consumer samples available to YouGov/Polimetrix-which are representative of the US population-and the characteristics of these individuals were recorded. A subset of the respondents to the online survey were then selected by matching them-based on a set of demographic characteristics-to the individuals randomly drawn from the population (i.e., from the consumer files), using age, race, gender, income, education, and media usage. Propensity scores were then developed to ensure that the sample would match the characteristics of the US adult population as reflected in the 2004 Current Population Survey. ${ }^{17}$

The Internet-based design has the important advantage of allowing researchers to base their analysis on a large sample of 36,421 individuals. As all survey designs, it faces some important limitations. In particular, as has been pointed out by Hill et al. (2007), the approach followed by Polimetrix does not attempt to match respondents to target populations on political engagement or partisan commitment. Still, methodological analyses have concluded that "[...]although the opt-in Internet sample we analyze does have some bias, the bias is probably not so great as to vitiate the gains of inexpensive, large and targeted samples that the Internet methodology makes possible[...]" (Hill et al. 2007). The CCES has already been used in several papers, ranging from the analysis of the determinants of US trade policy carried out by Guisinger (2009) to the study of the causes and consequences of public misperceptions of the size of the US immigrant population carried out by Citrin and Sides (2008).

The main dependent variable in our empirical analysis is the answer to a question about whether the respondent is in favor of the Senate plan, which offered a path to legalization and citizenship to illegal immigrants. The exact wording is as follows: "Another issue is illegal immigration. One plan considered by the Senate would offer illegal immigrants who already live in the U.S. more opportunities to become legal citizens. Some politicians argue that people who have worked hard in jobs that the economy depends on should be offered the chance to live here legally. Other politicians argue that the plan is an amnesty that rewards people who have broken the law. What do you think? If you were faced with this decision, would you vote for or against this proposal?" We create a pro_lenient_plan dummy variable which equals 1 if the respondent answers he would have voted for the Senate proposal and 0 if he/she would have turned it down. We exclude from the analysis those who have answered "don't know." 18

There is an additional question in the CCES regarding the respondent's likely vote on alternative illegal immigration proposals. In this case, the respondent is asked to give his comparative opinion about the Senate and the House plan. The exact wording of the question is as follows: "Congress has been debating different policies concerning immigration 
reform. The Senate proposal has a path to citizenship for illegal immigrants. The House proposal, on the other hand, contains stricter enforcement and deportation of undocumented aliens. Which of these two items of reform do you think is more important?" We create a pro_lenient_plan2 dummy variable which equals 1 if the respondent answers he would have voted for the Senate proposal and 0 if he/she would have voted for the House plan. We therefore exclude from the analysis those who have answered "Don't know." Since this question was asked to a subsample of 16,231 respondents (i.e., not to the entire sample but only to those who were interviewed in the pilot study, held in August 2006), we rely on this question solely for robustness checks of the main results.

Regarding media exposure, respondents are first asked to state the frequency with which they watched a national evening news program in the week before the interview. For those who watched a news program at least once, there is an additional question, which asks them to mention the most frequently watched network for national evening news. ${ }^{19}$ We create separate dummies for each most frequently watched network and an additional dummy for those who did not watch a national evening news program (the no_evening_news dummy).

The CCES survey also contains information on the age, gender, education, household income, employment status, immigration status, and political views of respondents. Education is coded according to a 1-6 ordered scale, with a value of 1 for those who have not completed high school and 6 for those with a post-graduate degree. Individuals are asked to classify their own income along a discrete scale of 14 income "brackets," with interval size increasing from $\$ 5,000$ to $\$ 30,000 .{ }^{20}$ Previous research (Scheve and Slaughter 2001; Mayda 2006) shows that the correlation between education and immigration attitudes is a function of labor force participation. Building on a question on employment status, we thus construct a dummy variable which equals 1 when the respondent belongs to the labor force, i.e., he/she is working full time or part time or is unemployed, and 0 otherwise.

Another question in the CCES survey provides information on the immigration status of the respondent. We use it for two different purposes: first, we exclude from the statistical analysis those who declare to be immigrants; second, for those who are US citizens and hence are included in our analysis, we use the question in order to extract some information on the family origin of the respondent. More specifically, we create a discrete variable (immigrant origin) on a 1-3 ordered scale, with a value of 1 for those whose parents and grandparents are US citizens; a value of 2 for those whose parents are US citizens, but at least one grandparent is an immigrant; and a value of 3 for those who declare that at least one of their parents is foreign-born.

Regarding political controls, the CCES survey has a question on self-reported ideology: individuals are asked to locate themselves on an ideological 0-100 scale, ranging from 0 for extremely liberal views to 100 for extremely conservative ones. Moreover, there are two variables measuring the party identification of the respondent. The first variable is a 3-point scale party id variable, which equals -1 for self-identified Democrats, 0 for Independents, and 1 for Republicans. The second variable is a 7-point scale indicator, ranging from 1 for strong Democrats to 7 for strong Republicans.

One might consider religion as an organized system of beliefs which could be systematically correlated with attitudes regarding policy issues. Among others, the CCES survey contains a question about the religious preferences of the respondent and one about the frequency of church attendance. We recode the church attendance variable as an ordinal 
one, which ranges from a value of 0 for those who declare to go to church "never or almost never" to a value of 3 for those who (declare to) go at least once a week or more. Moreover, the survey also includes a question on the perceived importance of religion in everyday life. In Section 6, we explore whether our baseline results are robust to controlling for the religious attitudes of respondents.

Whether the respondent lives in an urban, suburban, or rural area might be correlated with the type and frequency of encounters with illegal immigrants and hence with his/her views on the issue. Also, it can be correlated with other unobserved features of his/her political views. Since respondents are not asked about their location in terms of urban, suburban, or rural area but are asked about their county of residence, we match the CCES data with county-level information, which are taken from the ICPSR County Characteristics File. ${ }^{21}$ In particular, for each county, we calculate a measure of population density in 2005 , by dividing population in that year by land area, as expressed in square miles. This density measure is in turn expressed in tens of thousands. The only reasonable proxy for the rural-urban location which is directly available in the CCES survey is a question about whether the respondent owns a pickup truck. We use this variable in Section 6.

Other county-level and state-level features might be correlated with our dependent variable and other explanatory variables. More specifically, in Section 6, we control for the unemployment rate in 2005 and the crime rate for every 100 inhabitants in 2004, both measured at the county level. Finally, we match the CCES data with information on the estimated fraction of illegal immigrants (over total population) living in each state in year 2005. The estimated number of illegal immigrants by state is calculated by the Pew Hispanic Center, while total population data is taken from the US Census Bureau. We also compute a measure of the fraction of legal immigrants over total population in 2005. The number of legal immigrants by state is computed as the difference between the number of foreign-born individuals and the number of illegal immigrants. The number of foreign-born individuals is derived from the Pew Hispanic Center tabulations of the Census Bureau's 2005 American Community Survey. ${ }^{22}$

Summary statistics of these variables are shown in Table 2, separately for individual-, county-, and state-level variables. The large majority of respondents is against the Senate plan. Regarding the most frequently watched national evening news program, Fox News obtains the highest ratings, with NBC and CNN ranking second and third, respectively. Age, education, and household income are positively skewed, and this is also the case for the conservative ideology score.

At the county level, the population density, unemployment, and crime rate are all positively skewed and show a sizeable degree of cross-sectional variation. Regarding statelevel variables, the estimated fraction of illegal immigrants displays some non-negligible variation as well, ranging from a quarter of a percentage point for West Virginia to around 7 percentage points for California. This also applies to the fraction of legal immigrants, which ranges from about a fifth of a percentage point for Mississippi to almost 20 percentage points again for California.

\section{Empirical results}

In this section, we empirically analyze the individual-level propensity to support the Senate plan on illegal immigration as a function of respondents' characteristics. We run a set of probit regressions with the pro_lenient_plan dummy as the dependent variable, 
Table 2 Summary statistics

\begin{tabular}{|c|c|c|c|c|c|c|}
\hline Variable & No of obs. & Mean & Median & Std. dev. & Min & Max \\
\hline \multicolumn{7}{|l|}{ Individual level } \\
\hline Pro_lenient_plan dummy & 24,546 & 0.385 & 0 & 0.487 & 0 & 1 \\
\hline Pro_lenient_plan2 dummy & 11,050 & 0.289 & 0 & 0.454 & 0 & 1 \\
\hline Age & 24,546 & 48.773 & 49 & 14.886 & 18 & 93 \\
\hline Female dummy & 24,546 & 0.485 & 0 & 0.500 & 0 & 1 \\
\hline Black dummy & 24,546 & 0.097 & 0 & 0.297 & 0 & 1 \\
\hline Latino dummy & 24,546 & 0.081 & 0 & 0.273 & 0 & 1 \\
\hline Immigrant origin & 24,546 & 1.425 & 1 & 0.645 & 1 & 3 \\
\hline Education & 24,546 & 3.338 & 3 & 1.366 & 1 & 6 \\
\hline Household income & 24,546 & 8.388 & 8 & 3.315 & 1 & 14 \\
\hline Labor force dummy & 24,546 & 0.671 & 1 & 0.470 & 0 & 1 \\
\hline Conservative ideology (100-point scale) & 19,333 & -0.006 & 0 & 0.829 & -1 & 1 \\
\hline Party id (3-point scale) & 24,546 & 55.249 & 51 & 27.278 & 0 & 100 \\
\hline Party id (7-point scale) & 24,546 & 3.992 & 4 & 2.187 & 1 & 7 \\
\hline ABC World News dummy & 20,354 & 0.100 & 0 & 0.300 & 0 & 1 \\
\hline CBS Evening News dummy & 20,354 & 0.076 & 0 & 0.265 & 0 & 1 \\
\hline CNN dummy & 20,354 & 0.103 & 0 & 0.304 & 0 & 1 \\
\hline Fox News dummy & 20,354 & 0.216 & 0 & 0.411 & 0 & 1 \\
\hline PBS The NewsHour dummy & 20,354 & 0.043 & 0 & 0.202 & 0 & 1 \\
\hline NBC Nightly News dummy & 20,354 & 0.132 & 0 & 0.338 & 0 & 1 \\
\hline MSNBC dummy & 20,354 & 0.050 & 0 & 0.218 & 0 & 1 \\
\hline Other networks dummy & 20,354 & 0.014 & 0 & 0.118 & 0 & 1 \\
\hline No evening news dummy & 20,409 & 0.266 & 0 & 0.442 & 0 & 1 \\
\hline Pickup truck dummy & 24,426 & 0.337 & 0 & 0.473 & 0 & 1 \\
\hline Protestant dummy & 24,209 & 0.366 & 0 & 0.482 & 0 & 1 \\
\hline Catholic dummy & 24,209 & 0.206 & 0 & 0.404 & 0 & 1 \\
\hline Jewish dummy & 24,209 & 0.017 & 0 & 0.128 & 0 & 1 \\
\hline Muslim dummy & 24,209 & 0.002 & 0 & 0.044 & 0 & 1 \\
\hline Other religion dummy & 24,209 & 0.067 & 0 & 0.250 & 0 & 1 \\
\hline Other Christian religion dummy & 24,209 & 0.151 & 0 & 0.358 & 0 & 1 \\
\hline No favorite religion dummy & 24,209 & 0.191 & 0 & 0.393 & 0 & 1 \\
\hline Church attendance & 24,210 & 1.164 & 1 & 1.268 & 0 & 3 \\
\hline Importance of religion & 24,452 & 0.683 & 1 & 0.465 & 0 & 1 \\
\hline \multicolumn{7}{|l|}{ County level } \\
\hline Population density, 2005 & 2280 & 0.030 & 0.006 & 0.196 & 0.00003 & 6.939 \\
\hline Unemployment rate, 2005 & 2273 & 5.364 & 5.100 & 1.608 & 1.9 & 16.000 \\
\hline Crime rate, 2004 & 2154 & 3.017 & 2.684 & 1.678 & 0 & 12.633 \\
\hline \multicolumn{7}{|l|}{ State level } \\
\hline Fraction of illegal immigrants, 2005 & 50 & 2.576 & 2.146 & 1.869 & 0.275 & 7.265 \\
\hline Fraction of legal immigrants, 2005 & 50 & 5.338 & 4.012 & 4.524 & 0.213 & 19.436 \\
\hline
\end{tabular}

The pro_lenient_plan dummy equals 1 if the respondent would have voted in favor of the Senate plan on illegal immigration and 0 if he/she would have voted against. See the text for additional details. Party id equals $1(-1)$ if the respondent identifies himself/herself as a Republican (Democrat) and 0 for a self-identified Independent

Sources: The individual-level variables are taken from the CCES survey. The fraction of illegal immigrants per state in 2005 is the estimated number of illegal immigrants (as calculated by the Pew Hispanic Center) divided by state population (as estimated by the US Census Bureau). The fraction of legal immigrants by state is computed as the difference between the number of

foreign-born individuals and the number of illegal immigrants, divided by state population. County-level variables are taken from the ICPSR Study No. 20660

excluding all individuals who describe themselves as immigrants. The regression output is displayed in Table 3 where, for each explanatory variable, we report the marginal effect. Standard errors are adjusted for clustering at the state level and are shown under each marginal effect. 
Table 3 Correlates of attitudes towards illegal immigration, baseline results

\begin{tabular}{|c|c|c|c|c|c|c|c|}
\hline \multirow{2}{*}{$\begin{array}{l}\text { Dependent variable } \\
\text { Estimation method }\end{array}$} & \multicolumn{7}{|c|}{ Pro_lenient_plan dummy } \\
\hline & $\begin{array}{l}\text { Probit } \\
\text { [1] }\end{array}$ & $\begin{array}{l}\text { Probit } \\
{[2]}\end{array}$ & $\begin{array}{c}\text { Probit } \\
\text { [3] }\end{array}$ & $\begin{array}{c}\text { Probit } \\
{[4]}\end{array}$ & $\begin{array}{l}\text { Probit } \\
{[5]}\end{array}$ & $\begin{array}{c}\text { Probit } \\
{[6]}\end{array}$ & $\begin{array}{c}\text { Probit } \\
\text { [7] }\end{array}$ \\
\hline \multirow[t]{2}{*}{ Age } & $-0.018^{c}$ & $-0.014^{c}$ & $-0.014^{c}$ & $-0.014^{c}$ & $-0.014^{c}$ & $-0.011^{c}$ & $-0.013^{c}$ \\
\hline & {$[0.001]$} & {$[0.002]$} & {$[0.002]$} & {$[0.002]$} & {$[0.002]$} & {$[0.002]$} & {$[0.002]$} \\
\hline \multirow[t]{2}{*}{ Age squared } & $0.000^{c}$ & $0.000^{c}$ & $0.000^{c}$ & $0.000^{c}$ & $0.000^{c}$ & $0.000^{c}$ & $0.000^{c}$ \\
\hline & {$[0.000]$} & {$[0.000]$} & {$[0.000]$} & {$[0.000]$} & {$[0.000]$} & {$[0.000]$} & {$[0.000]$} \\
\hline \multirow[t]{2}{*}{ Female dummy } & $0.034^{c}$ & 0.009 & 0.008 & 0.008 & 0.008 & 0.01 & 0.006 \\
\hline & {$[0.007]$} & {$[0.007]$} & {$[0.008]$} & {$[0.008]$} & {$[0.008]$} & [0.009] & {$[0.008]$} \\
\hline \multirow[t]{2}{*}{ Black dummy } & $0.075^{c}$ & 0.016 & 0.002 & 0.008 & 0.01 & 0.001 & 0.006 \\
\hline & {$[0.016]$} & {$[0.016]$} & {$[0.016]$} & {$[0.017]$} & {$[0.017]$} & {$[0.018]$} & [0.019] \\
\hline \multirow[t]{2}{*}{ Latino dummy } & $0.225^{c}$ & $0.221^{c}$ & $0.209^{c}$ & $0.203^{c}$ & $0.205^{c}$ & $0.212^{c}$ & $0.219^{c}$ \\
\hline & {$[0.019]$} & {$[0.024]$} & {$[0.023]$} & {$[0.023]$} & {$[0.021]$} & {$[0.026]$} & {$[0.026]$} \\
\hline \multirow[t]{2}{*}{ Immigrant origin } & $0.027^{c}$ & $0.017^{c}$ & $0.017^{c}$ & $0.017^{c}$ & $0.018^{c}$ & $0.019^{c}$ & $0.021^{c}$ \\
\hline & {$[0.006]$} & {$[0.005]$} & {$[0.005]$} & {$[0.005]$} & {$[0.005]$} & {$[0.006]$} & {$[0.006]$} \\
\hline \multirow[t]{2}{*}{ Education } & $0.046^{c}$ & $0.041^{c}$ & $0.040^{c}$ & $0.040^{c}$ & $0.041^{c}$ & $0.042^{c}$ & $0.040^{c}$ \\
\hline & {$[0.004]$} & {$[0.004]$} & {$[0.004]$} & {$[0.004]$} & {$[0.004]$} & {$[0.005]$} & {$[0.005]$} \\
\hline \multirow[t]{2}{*}{ Income } & 0.001 & $0.004^{c}$ & $0.004^{c}$ & $0.004^{c}$ & $0.005^{c}$ & $0.004^{b}$ & $0.004^{b}$ \\
\hline & {$[0.001]$} & {$[0.001]$} & {$[0.001]$} & {$[0.001]$} & {$[0.001]$} & {$[0.002]$} & {$[0.002]$} \\
\hline \multirow{2}{*}{$\begin{array}{l}\text { Conservative ideology } \\
\text { (100-point scale) }\end{array}$} & - & $-0.006^{c}$ & $-0.005^{c}$ & $-0.005^{c}$ & $-0.005^{c}$ & $-0.005^{c}$ & $-0.005^{c}$ \\
\hline & & {$[0.000]$} & {$[0.000]$} & {$[0.000]$} & {$[0.000]$} & {$[0.000]$} & {$[0.000]$} \\
\hline \multirow[t]{2}{*}{ Party id (3-point scale) } & - & $-0.051^{c}$ & - & - & - & - & - \\
\hline & & {$[0.009]$} & & & & & \\
\hline \multirow[t]{2}{*}{ Party id (7-point scale) } & - & - & $-0.027^{c}$ & $-0.027^{c}$ & $-0.028^{c}$ & $-0.031^{c}$ & $-0.026^{c}$ \\
\hline & & & {$[0.004]$} & {$[0.004]$} & {$[0.004]$} & {$[0.005]$} & {$[0.004]$} \\
\hline \multirow[t]{2}{*}{$A B C$ dummy } & $-0.046^{c}$ & $-0.031^{b}$ & $-0.034^{b}$ & $-0.032^{b}$ & $-0.036^{b}$ & - & - \\
\hline & {$[0.014]$} & {$[0.014]$} & {$[0.014]$} & {$[0.014]$} & {$[0.015]$} & & \\
\hline \multirow[t]{2}{*}{ CNN dummy } & $-0.051^{c}$ & $-0.081^{c}$ & $-0.089^{c}$ & $-0.088^{c}$ & $-0.089^{c}$ & - & - \\
\hline & {$[0.018]$} & {$[0.018]$} & {$[0.016]$} & {$[0.016]$} & {$[0.016]$} & & \\
\hline \multirow[t]{2}{*}{ FOX News dummy } & $-0.258^{c}$ & $-0.103^{c}$ & $-0.094^{c}$ & $-0.093^{c}$ & $-0.096^{c}$ & - & - \\
\hline & {$[0.015]$} & {$[0.015]$} & {$[0.015]$} & {$[0.015]$} & {$[0.015]$} & & \\
\hline \multirow[t]{2}{*}{ PBS dummy } & $0.226^{c}$ & $0.151^{c}$ & $0.139^{c}$ & $0.137^{c}$ & $0.136^{c}$ & - & - \\
\hline & {$[0.023]$} & {$[0.023]$} & {$[0.023]$} & {$[0.023]$} & {$[0.024]$} & & \\
\hline \multirow[t]{2}{*}{ NBC dummy } & -0.006 & 0.002 & 0 & 0 & -0.003 & - & - \\
\hline & {$[0.015]$} & {$[0.016]$} & {$[0.016]$} & {$[0.016]$} & {$[0.016]$} & & \\
\hline \multirow[t]{2}{*}{ MSNBC dummy } & 0.037 & -0.017 & -0.018 & -0.018 & -0.021 & - & - \\
\hline & {$[0.025]$} & {$[0.022]$} & {$[0.021]$} & {$[0.021]$} & {$[0.022]$} & & \\
\hline \multirow[t]{2}{*}{ Other network dummy } & 0.008 & 0.004 & 0.01 & 0.008 & 0.009 & - & - \\
\hline & {$[0.030]$} & {$[0.030]$} & {$[0.030]$} & {$[0.030]$} & {$[0.031]$} & & \\
\hline \multirow[t]{2}{*}{ No evening news dummy } & $-0.103^{c}$ & $-0.040^{b}$ & $-0.037^{b}$ & $-0.038^{b}$ & $-0.041^{b}$ & - & - \\
\hline & {$[0.015]$} & {$[0.016]$} & {$[0.016]$} & {$[0.016]$} & {$[0.017]$} & & \\
\hline \multirow{2}{*}{$\begin{array}{l}\text { Count of stories on illegal } \\
\text { immigration on the } \\
\text { favorite news broadcast }\end{array}$} & - & - & - & - & - & - & $-0.001^{c}$ \\
\hline & & & & & & & {$[0.000]$} \\
\hline Count of stories about & - & - & - & - & - & - & $-0.001^{c}$ \\
\hline & & & & & & & {$[0.000]$} \\
\hline Population density & - & - & $0.030^{c}$ & $0.032^{c}$ & $0.033^{c}$ & $0.027^{c}$ & $0.028^{c}$ \\
\hline & & & {$[0.008]$} & {$[0.009]$} & {$[0.007]$} & {$[0.008]$} & {$[0.008]$} \\
\hline
\end{tabular}


Table 3 Correlates of attitudes towards illegal immigration, baseline results (Continued)

\begin{tabular}{|c|c|c|c|c|c|c|c|}
\hline \multirow{2}{*}{$\begin{array}{l}\text { Fraction of illegal } \\
\text { immigrants (state level) }\end{array}$} & - & - & $0.007^{c}$ & - & - & $0.007^{c}$ & $0.007^{c}$ \\
\hline & & & {$[0.003]$} & & & {$[0.003]$} & {$[0.003]$} \\
\hline \multirow{2}{*}{$\begin{array}{l}\text { Fraction of legal } \\
\text { immigrants (state level) }\end{array}$} & - & - & -0.001 & - & - & -0.002 & -0.002 \\
\hline & & & {$[0.001]$} & & & {$[0.001]$} & {$[0.001]$} \\
\hline State fixed effects & No & No & No & Yes & No & No & No \\
\hline DMA fixed effects & No & No & No & No & Yes & No & No \\
\hline Pseudo $R$-squared & 0.1 & 0.17 & 0.17 & 0.18 & 0.18 & 0.15 & 0.16 \\
\hline Observations & 19,401 & 19,401 & 20,422 & 20,422 & 20,409 & 13,656 & 13,656 \\
\hline
\end{tabular}

The sample excludes all individuals who describe themselves as immigrants. The dependent variable is a dummy which takes on the value of 1 if the respondent would have voted in favor of the Senate plan on illegal immigration and 0 otherwise. The panel contains the estimated marginal effect on the probability of being in favor of the Senate plan, given an increase in the value of the relevant regressor, holding all other regressors at their mean values. Income is coded according to a 1-14 ordered scale of income brackets. Education is coded according to a 1-6 ordered scale, ranging from a value of 1 from high school dropouts to 6 for those holding a post-graduate degree. The immigrant origin variable is coded as follows: 1, parents and grandparents were born in the US; 2, parents were born in the US but at least one grandparent is an immigrant; and 3, at least one parent is an immigrant. The conservative ideology variable is coded on a 0-100 scale, with 0 for extremely liberal views and 100 for extremely conservative ones. The 3-point scale variable for party identification takes on a value of -1 for a Democrat, 0 for an Independent, and 1 for a Republican. The 7-point scale party id variable takes on values on the 1-7 range, with 1 for a strong Democrat to 7 for a strong Republican. Each of the network dummy equals 1 when the respondent declares that he most frequently watches the evening news broadcast on network x and 0 otherwise. CBS is the excluded network. The "no evening news" dummy equals 1 when the respondent declares that in the past week, he never watched a national evening news program and 0 otherwise. The count of stories on illegal immigration on the favorite evening news broadcast is the number of stories in 2005 where the expressions "illegal immigration" or "illegal immigrants" appear. Exploiting the Dow Jones Factiva archive, this is done for ABC, CBS, CNN, Fox News, PBS, and NBC. Population density (in tens of thousands) is calculated at the county level as the number of inhabitants by square mile in 2005. The state-specific fraction of illegal (and legal) immigrants is calculated for 2005 and is expressed in percentage points

a Significant at $1 \%$;

${ }^{b}$ significant at $5 \%$

${ }^{c}$ significant at $1 \%$

Notice that, in the CCES question we analyze, individuals are asked to evaluate the Senate plan but are not mentioned any explicit alternative. ${ }^{23}$ The interpretation of the marginal effects of a number of variables (in particular, education and income) depends on which alternative voters have in mind-whether the status quo or the House plan-as they evaluate the Senate plan. To shed light on this point, we run the same regressions as in Table 3 using the second question-the pro_lenient_plan2 dummy variable-as the dependent variable (see Table 7 in the Appendix). We find that the estimates of the marginal effects of most variables in Table 7 in the Appendix are very similar to the corresponding estimates in Table $3 .^{24}$ As a result, we conclude that the alternative respondents have in mind, as they evaluate the Senate plan, is the House plan.

\subsection{The impact of media exposure on individual attitudes}

In Table 3, we report our baseline results. We start with a specification where we omit ideological and political party controls (regression [1]). Next, in column [2], we introduce the conservative ideology score and the 3-point party id variable. In regression [3], we replace the 3-point party id variable with a 7-point one and we include the countyspecific measure of population density as well as the state-specific measures of exposure to illegal and legal immigration. In columns [4] and [5], we introduce state and designated market area (DMA) fixed effects, respectively. ${ }^{25}$ In the first five columns of Table 3, we use dummy variables for each media channel, with CBS viewers as the omitted category. 
In order to analyze the role played by media exposure-in particular in relation to self-selection issues-it is crucial to compare the estimates with and without ideological controls, i.e., column [1] vs. columns [2]-[5]. By themselves, political and ideological variables are very significant predictors of policy attitudes towards illegal immigration. A 1 -point increase in the conservative ideology scale (which is defined on a $0-100$ range) is associated with about half of a percentage point decrease in the probability of supporting the Senate plan. By the same token, the 3-point party id variable is negatively and significantly correlated with the lenient plan dummy, and the same is true for the 7-point party id, which we introduce from column [3]. When not controlling for self-reported ideology and party identification, individuals watching Fox News are 26 percentage points less likely to support the Senate plan-as compared to CBS viewers (the excluded category) while this marginal effect shrinks to between 9 and 10 percentage points when we do control for ideological and partisan preferences. Similarly, PBS viewers are 23 percentage points more likely than CBS viewers to support the lenient plan in column [1] and between 14 and 15 percentage points in the following columns. To the extent that conservative individuals have a preference for Fox News and dislike the Senate plan on illegal immigration, omitting controls for ideology and party id biases downwards the marginal effect of the Fox News dummy, which ends up absorbing those self-selection effects. ${ }^{26}$ Along the same lines, to the extent that liberal individuals appreciate PBS and the more lenient Senate plan, the marginal effect of the PBS dummy is biased upwards when not controlling for ideology and party id.

On the other hand, those watching $\mathrm{CNN}$ are about 5 percentage points less likely to favor the Senate plan when not controlling for ideology and between 8 and 9 percentage points less likely when doing so. Prima facie, it is perhaps surprising that those watching $\mathrm{CNN}$ are systematically less likely to support the Senate plan than CBS viewers, but this result can be explained in light of what in Section 1 we have dubbed the "Lou Dobbs effect." ${ }^{27}$ Lou Dobbs, the former anchor and managing editor of CNN evening news, has been very vocal regarding the costs imposed by illegal immigration on the American public and has consistently opposed the Senate bill proposal. This is how he described illegal immigration on his $\mathrm{CNN}$ website: "The single most critical issue to protect our nation is the securing of our borders and our ports. Every day, tens of thousands of containers enter our country from other nations and they are never inspected. At the same time, our government turns a blind eye to the thousands of people who illegally cross our borders. These scenarios exist because corporate America has convinced our leaders that this is one of the best ways to remain competitive." When the Senate passed the Comprehensive Immigration Reform Act, Lou Dobbs introduced the story with the following words: "Tonight, the Senate has just voted for a so-called comprehensive immigration reform bill. The vote, 62-36. The legislation gives amnesty to millions of illegal aliens and sharply escalates the war on our middle class and raises the cost of federal government substantially." 28 From the point of view of ideological selfselection, the bias towards 0 of the $\mathrm{CNN}$ dummy variable in regression [1] -induced by omitting ideological controls-suggests that CNN viewers are more liberal than CBS viewers (the omitted category). In addition, and most importantly, the result for CNNthat the impact of the news program works in the opposite direction with respect to self-selection-gives us confidence that our correlations are at least in part driven by the causal impact of media exposure. In other words, the coefficient on CNN represents, 
if anything, a lower bound on the causal impact of CNN on attitudes towards illegal immigrants.

It is also interesting to notice that the marginal effects of media exposure are remarkably stable once we start controlling for ideological and partisan preferences. As mentioned above, beginning with column [3], we replace the 3-point party id variable with the 7point one, but this does not affect our estimates of the media exposure variables. ${ }^{29}$

Focusing on the other media channels, individuals watching NBC, MSNBC, or other networks appear not to be significantly different from CBS viewers in their propensity to support the more lenient immigration plan, while viewers of $A B C$ News are systematically less likely to favor the Senate plan than CBS viewers, with an estimated marginal effect between 3 and 4 percentage points. Finally, respondents declaring not to watch any national evening news program are significantly less likely than CBS viewers to be in favor of the Senate plan.

Overall, the evidence we have gathered is consistent with the fact that self-selection explains a sizeable portion of the correlation between policy attitudes on illegal immigration and media exposure, but not the whole of it: persuasion, as best exemplified by the Lou Dobbs effect, appears to be a non-negligible factor. How do the effects of media exposure relate to the ideological position of each TV channel? In other words, is it true that more conservative channels have a more negative impact on the probability of supporting the lenient Senate plan? If one believes that self-selection is satisfactorily accounted for by controlling for the ideology and party id of the respondent, then the estimated marginal effect of each channel dummy measures the persuasive effect of that channel on attitudes towards illegal immigration. Our goal is to relate this persuasive effect to the ideological position of the TV channel. While measures of the partisan stance of media outlets are available in the literature, we can directly exploit the self-selection argument in order to build our own measure of each TV channel's ideological position. To do so, we proceed as follows. A given TV channel reveals itself to be less conservative than CBS if it is chosen by people who are less conservative than the (omitted) category of CBS viewers. In turn, this is true if and only if the marginal effect of that channel dummy is more positive when not controlling for the ideology and party id of the respondents than when doing so. More formally, let the marginal effect of a TV channel dummy in regression (1) be $\delta_{1}$ and the marginal effect of the same TV channel in regression (5) be $\delta_{5}$. In turn, $\delta_{1}=\delta_{5}+$ OVB where OVB is the omitted variable bias arising from the omission of ideological controls. We know that

$$
\text { OVB } \propto \text { Corr(Ideology, TVChannel) } \times \text { Corr(Ideology, Attitudes }),
$$

where Ideology represents the self-reported (conservative) ideology variable. In other words, the omitted variable bias is proportional to the product of the correlation between our measure of viewers' ideology and the observed TV channel and of the correlation between our measure of viewer's ideology and attitudes towards illegal immigration. If $\delta_{1}>\delta_{5}$, it must be true that OVB $>0$, and therefore, since our estimates suggest that Corr(Ideology, Attitudes) $<0$, then it must be true that Corr(Ideology, TVChannel) $<0$, i.e., the TV channel is not watched by viewers with conservative ideology. In other words, the TV channel reveals itself to be less conservative than the CBS benchmark, based on the preferences of viewers who choose it. In particular, the expression above suggests to divide the estimated OVB by the correlation between ideology and immigration attitudes, 
in order to obtain a normalized measure of the average conservative ideology of each TV channel.

The outcome of this exercise is illustrated in Fig. 1 where-for each TV channel-we plot the estimated marginal effect—on the propensity to support the Senate plan-against its overall ideological position on a liberal-conservative scale. More precisely, the former is taken from column [5] in Table 3, while the latter is calculated as the difference in the estimated marginal effect of each channel dummy between specification [1] and specification [5], again in Table 3, divided by the estimated correlation of the conservative ideology score with attitudes. The relationship appears to be negative, since more conservative channels like Fox News are associated with a more negative effect on the propensity to support the Senate plan, and vice versa for a liberal channel like PBS. It is especially interesting to focus on the relative position of $\mathrm{CNN}$, which is close to CBS and NBC from the point of view of the overall ideological position (as revealed by its viewers), but has a negative effect on immigration attitudes, the size of which is comparable to that of Fox News. ${ }^{30}$

The exposure to real-world events is also likely to affect individual attitudes or at least to be a significant predictor thereof. At the county level, population density is positively and significantly correlated with the propensity to support the Senate plan: column [3] in Table 3 shows that an increase of density of 10,000 individuals per square mile is associated with a 3-percentage-point increase in the probability of being in favor of the more lenient immigration plan. This result is consistent with the idea that living in an urban area increases the frequency of encounters with illegal immigrants and hence positively

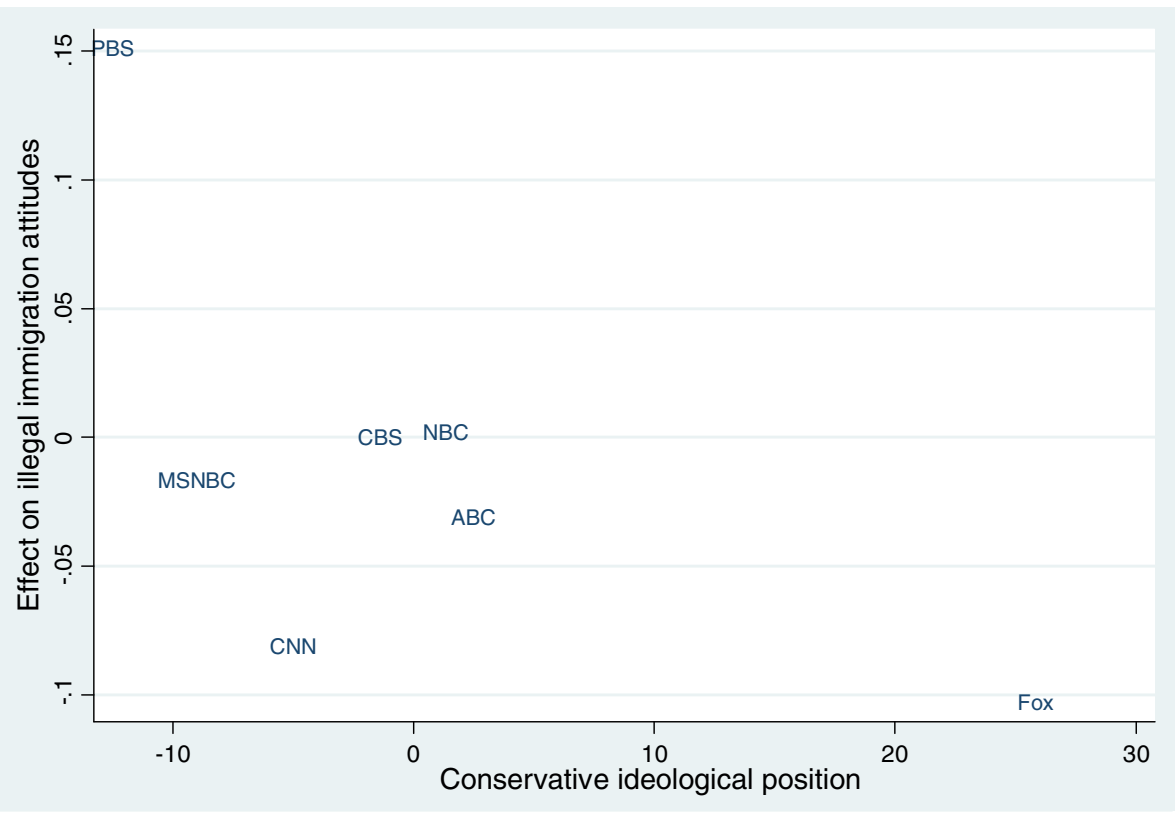

Fig. 1 Estimated ideological position of each TV channel and effect on illegal immigration attitudes. Notes: The graph displays the estimated marginal effect on the propensity to support the Senate plan for each TV channel against its overall ideological position. The former is taken from column [2] in Table 3. The latter is a measure of conservative ideology and is calculated as the difference in the estimated marginal effect of each channel dummy when moving from specification [1] to specification [2], i.e., when including ideological and party id controls, divided by the estimated correlation between the ideology score and migration attitudes. See Section 5.1 for additional details 
affects the respondent's views on the issue. Thus, this finding resonates with the so-called intergroup contact theory (Allport 1954). According to this theory, as developed within the field of social psychology, the interaction between different racial groups can reduce prejudice and foster more friendly attitudes. Also, living in an urban area is likely to be correlated with other unobserved features of the respondent's political views.

In column [3], we also control for the state-specific fraction of illegal immigrants: we find that respondents living in states with a higher fraction of illegal immigrants are significantly more likely to support the more lenient Senate plan. The size of this correlation is quite large, as a 1-percentage-point increase in the fraction of illegals is associated with a 0.7-percentage-point increase in the propensity to support the Senate plan. This result is again consistent with the "intergroup contact theory." One might be concerned that the partial correlation between attitudes and the state-specific fraction of illegal immigrants is picking up some omitted variable at the state level, e.g., exposure to legal immigrants. Thus, we also control for the state-specific fraction of legal immigrants and find that it is not significantly correlated with the dependent variable. Columns [4]-[5] replicate the specification featured in column [3] but with the addition of state and DMA fixed effects, respectively: the estimated marginal effects are remarkably robust to this change.

In the second part of Table 3, we further investigate the relationship between immigration attitudes and the respondent's favorite evening news broadcast. In particular, we check whether the way each news broadcast covers illegal immigration helps explain the previously estimated marginal effects on the TV channel dummies. Both the overall amount and type of media coverage devoted to a certain issue could matter. In our case, we focus on overall coverage, since it can be easily measured in a replicable fashion. The Dow Jones Factiva online archive allows to search the transcripts of evening news programs on ABC, CBS, CNN, Fox News, PBS, and NBC. We proxy the total amount of coverage to which respondents are exposed-before being interviewed during the 2006 midterm campaign - with the broadcast-specific number of stories featuring the words "immigration" or "immigrants" between January 2006 and October 2006. We do the same with the search terms "illegal immigration" or "illegal immigrants," and we compute the difference between those two counts, in order to obtain a measure of immigration coverage that does not mention illegal immigration. ${ }^{31}$

Table 8 in the Appendix reports media coverage data for each of the six TV channels. It is interesting to notice that Fox News and CNN devoted the largest amount of coverage to immigration overall, while PBS and CBS devoted the least. However, when looking at illegal immigration, PBS dedicated much less coverage than CBS, while CNN gave more coverage than Fox.

In the second part of Table 3, for comparison purposes, we start with a baseline specification (column [6]) which includes only the respondents mentioning the six channels as favorite ones-thus, we exclude respondents who do not watch a national evening news program-but we do not control for media coverage variables. In column [7], we add as regressors the channel-specific count of stories mentioning illegal immigration and the channel-specific count of stories mentioning immigration but not the illegal aspect of it. There is a very strong and negative correlation between those measures of media coverage and the propensity to support the Senate plan. In terms of magnitudes, ten additional illegal immigration stories during the January/October 2006 period are associated with a 1-percentage-point decrease in the probability of supporting the more lenient plan on 
immigration. The size of the effect for stories mentioning immigration but not the illegal one is the same. All other estimated marginal probabilities are practically unaffected by this cardinal specification of the media exposure variable.

This last result-i.e., the sizeable and significant impact of the number of immigrationrelated stories on the propensity to support the Senate plan-is interesting because it provides additional evidence that the media effects we are estimating are not driven only by self-selection. As a matter of fact, while it is plausible that individuals self-select into evening news programs based on the broad ideological position of the channel, it is less likely that self-selection works on the basis of the count of stories covering immigration.

Finally, for the specific result on the impact of FOX news, we are able to provide causal evidence based on an instrument used in the literature (DellaVigna and Kaplan 2007). In particular, for each individual surveyed in the CCES data set, we used the information on county of residence and merged the survey data with information on the introduction of Fox News (and CNN) in US cable markets. ${ }^{32}$ To allow for a non-linear effect of the introduction of the channel, we used the number of years since it was introduced in the individual's county of residence and created three variables, each capturing the availability of Fox News (and CNN) in 1998, 2000, and 2003. In particular, each of the variables gives the percentage of the population in each county which could access the network in each of the 3 years. We used these variables as instruments for the respondent's consumption of Fox News as well as indicators for whether the individuals subscribe to cable or satellite TV, and the results are shown in Table 4. The first column reports OLS estimates, where we restrict the sample to the states for which the data on US cable markets are available. Columns 2 and 4 present the first stages of specifications where we, respectively, exclude and include the $\mathrm{CNN}$ variable, and columns 3 and 5 present the corresponding second-stage specifications. The first stage is strong in both cases, with a $F$ value of the excluded instruments equal to 11.33 (column 2) and 14.07 (column 4). The second-stage results, which are significant at the $5 \%$ level, confirm that Fox News consumption negatively impacts the probability that the respondent favors the more lenient (towards illegal migrants) Senate plan.

\subsection{Socio-demographic and economic determinants of individual attitudes}

Besides studying the role played by the media, the regressions reported in Table 3 allow us to analyze the labor market and welfare state determinants of attitudes in favor of legalization, accounting for a number of socio-demographic individual-level controls.

First, we find that the impact of age on the propensity to support the Senate plan is characterized by a U-shaped relationship, as shown by the negative marginal effect of age and the positive marginal effect of age squared. The estimated minimum in the propensity to support the Senate plan occurs at an age between 55 (column [2]) and 58 (column [1]). In other words, as they approach midlife, young respondents become more opposed to the legalization plan, while older respondents become more in favor as they move towards retirement. A plausible interpretation of the positive marginal effect for elderly individuals is that illegal immigrants - who would be legalized under the Senate plan and deported under the House plan-offer services which are mostly consumed by the old, for example, elderly care and landscaping services. 
Table 4 Instrumental variables

\begin{tabular}{|c|c|c|c|c|c|}
\hline \multirow[t]{2}{*}{ Estimation method } & \multirow{2}{*}{$\begin{array}{l}\text { OLS } \\
{[1]}\end{array}$} & \multicolumn{2}{|l|}{ IV } & \multicolumn{2}{|l|}{ IV } \\
\hline & & $\begin{array}{l}\text { First stage } \\
{[2]}\end{array}$ & $\begin{array}{l}\text { Second stage } \\
{[3]}\end{array}$ & $\begin{array}{l}\text { First stage } \\
{[4]}\end{array}$ & $\begin{array}{l}\text { Second stage } \\
{[5]}\end{array}$ \\
\hline \multirow[t]{2}{*}{ Age } & $-0.012^{c}$ & $-0.003^{b}$ & $-0.013^{c}$ & $-0.004^{c}$ & $-0.013^{c}$ \\
\hline & {$[0.002]$} & {$[0.001]$} & {$[0.002]$} & {$[0.001]$} & {$[0.002]$} \\
\hline \multirow[t]{2}{*}{ Age squared } & $0.000^{c}$ & $0.000^{c}$ & $0.000^{c}$ & $0.000^{c}$ & $0.000^{c}$ \\
\hline & {$[0.000]$} & {$[0.000]$} & {$[0.000]$} & {$[0.000]$} & {$[0.000]$} \\
\hline \multirow[t]{2}{*}{ Female dummy } & 0.006 & -0.012 & 0.003 & $-0.013^{\mathrm{a}}$ & 0.003 \\
\hline & {$[0.009]$} & {$[0.008]$} & {$[0.009]$} & {$[0.008]$} & {$[0.009]$} \\
\hline \multirow[t]{2}{*}{ Black dummy } & 0.016 & $0.032^{b}$ & 0.024 & $0.036^{b}$ & 0.025 \\
\hline & {$[0.017]$} & {$[0.014]$} & {$[0.018]$} & {$[0.014]$} & {$[0.017]$} \\
\hline \multirow[t]{2}{*}{ Latino dummy } & $0.147^{c}$ & $0.053^{c}$ & $0.162^{c}$ & $0.055^{c}$ & $0.159^{c}$ \\
\hline & {$[0.019]$} & {$[0.016]$} & {$[0.021]$} & {$[0.016]$} & {$[0.020]$} \\
\hline \multirow[t]{2}{*}{ Immigrant origin } & 0.011 & $0.015^{b}$ & $0.016^{b}$ & $0.015^{b}$ & $0.015^{\mathrm{a}}$ \\
\hline & {$[0.007]$} & {$[0.006]$} & {$[0.008]$} & {$[0.006]$} & {$[0.008]$} \\
\hline \multirow[t]{2}{*}{ Education } & $0.039^{c}$ & $-0.012^{c}$ & $0.035^{c}$ & $-0.012^{c}$ & $0.036^{c}$ \\
\hline & {$[0.004]$} & {$[0.003]$} & {$[0.004]$} & {$[0.003]$} & {$[0.004]$} \\
\hline \multirow[t]{2}{*}{ Income } & $0.004^{c}$ & -0.001 & $0.005^{c}$ & -0.001 & $0.005^{c}$ \\
\hline & {$[0.001]$} & {$[0.001]$} & {$[0.002]$} & {$[0.001]$} & {$[0.002]$} \\
\hline \multirow[t]{2}{*}{ Conservative ideology (100-point scale) } & $-0.005^{c}$ & $0.003^{c}$ & $-0.004^{c}$ & $0.003^{c}$ & $-0.005^{c}$ \\
\hline & {$[0.000]$} & {$[0.000]$} & {$[0.000]$} & {$[0.000]$} & {$[0.000]$} \\
\hline \multirow[t]{2}{*}{ Part id (3-point scale) } & $-0.025^{c}$ & $0.047^{c}$ & -0.01 & $0.045^{c}$ & $-0.015^{c}$ \\
\hline & {$[0.003]$} & {$[0.003]$} & {$[0.007]$} & [0.003] & {$[0.006]$} \\
\hline \multirow[t]{2}{*}{ CNN dummy } & $-0.084^{c}$ & & & $-0.157^{c}$ & $-0.117^{c}$ \\
\hline & {$[0.015]$} & & & {$[0.013]$} & {$[0.022]$} \\
\hline \multirow[t]{2}{*}{ FOX News dummy } & $-0.066^{c}$ & & $-0.360^{c}$ & & $-0.286^{b}$ \\
\hline & {$[0.012]$} & & {$[0.127]$} & & {$[0.113]$} \\
\hline \multirow[t]{2}{*}{ Population density (county level) } & $0.058^{b}$ & -0.014 & $0.053^{b}$ & -0.014 & $0.054^{b}$ \\
\hline & {$[0.024]$} & {$[0.021]$} & {$[0.025]$} & {$[0.021]$} & {$[0.025]$} \\
\hline \multirow[t]{2}{*}{ Fraction of illegal immigrants (state level) } & 0.006 & -0.001 & 0.004 & -0.001 & 0.005 \\
\hline & {$[0.004]$} & {$[0.004]$} & {$[0.005]$} & {$[0.004]$} & {$[0.004]$} \\
\hline \multirow[t]{2}{*}{ Fraction of legal immigrants (state level) } & -0.001 & 0 & -0.001 & 0 & -0.001 \\
\hline & {$[0.001]$} & {$[0.001]$} & {$[0.002]$} & {$[0.001]$} & {$[0.002]$} \\
\hline \multirow[t]{2}{*}{ Share population Fox News available in 1998} & & $0.054^{b}$ & & $0.048^{\mathrm{a}}$ & \\
\hline & & {$[0.027]$} & & {$[0.026]$} & \\
\hline Share population CNN available in 1998 & & -0.005 & & -0.007 & \\
\hline & & {$[0.011]$} & & {$[0.011]$} & \\
\hline Share population Fox News available in 2000 & & 0.004 & & 0.005 & \\
\hline & & {$[0.016]$} & & {$[0.016]$} & \\
\hline Share population CNN available in 2000 & & -0.085 & & -0.083 & \\
\hline & & {$[0.062]$} & & {$[0.062]$} & \\
\hline Share population Fox News available in 2003 & & -0.006 & & -0.006 & \\
\hline & & {$[0.012]$} & & {$[0.012]$} & \\
\hline Share population CNN available in 2003 & & 0.061 & & $0.063^{\mathrm{a}}$ & \\
\hline & & {$[0.037]$} & & {$[0.037]$} & \\
\hline Cable TV subscriber dummy & & $0.099^{c}$ & & $0.111^{c}$ & \\
\hline & & {$[0.011]$} & & {$[0.011]$} & \\
\hline Satellite TV subscriber dummy & & $0.082^{c}$ & & $0.093^{c}$ & \\
\hline & & {$[0.012]$} & & {$[0.012]$} & \\
\hline$F$ test on excluded instruments & & 11.33 & & 14.07 & \\
\hline Sargan statistics & & 18.874 & & 18.741 & \\
\hline$P$ value on Sargan stats & & 0.0086 & & 0.009 & \\
\hline R2 & 0.22 & 0.19 & 0.15 & 0.19 & 0.19 \\
\hline N & 9318 & 9318 & 9318 & 9318 & 9318 \\
\hline
\end{tabular}


Moreover, females appear to be significantly more supportive of the Senate plan only when not controlling for ideology (column [1]). In fact, once we control for self-reported ideology and party id in the following regressions, we do not find evidence of a gender effect on pro-legalization attitudes. This result can be easily explained by the fact that women are on average more liberal than men so that-when not controlling for ideology - the ideology effect on illegal immigration attitudes is absorbed by the female dummy. A similar interpretation can be given to the marginal effect of the Black dummy variable, which is positive and significant in column [1] and becomes insignificant in the following regressions.

Not surprisingly, being a Latino has a positive and significant impact on pro-legalization attitudes, controlling or not for ideology and party id. Our estimates also show that individuals are more willing to support the Senate plan the more recent the immigration status of their family (as captured by immigrant origin). The size of this effect is relatively large: A one-point increase in the immigrant origin variable is associated with an approximately 2-percentage-point increase in the propensity to support the lenient immigration plan.

Respondents are significantly more likely to support the Senate plan, the higher their education level and their household income. Both correlations are strongly significant throughout the table, although the magnitude of the effect is larger for education. ${ }^{33}$

The positive impact of education on pro-legalization attitudes is consistent with the labor-market competition hypothesis (Scheve and Slaughter 2001; Kessler 2001; Mayda 2006; O'Rourke and Sinnott 2006). ${ }^{34}$ In fact, the Senate plan is likely to increases the labor market competition faced by unskilled natives-relative to the House plan. Since undocumented migrants are mostly unskilled, the effect of legalizing them, as opposed to deporting them, is to increase the relative supply of unskilled workers in the USA.

In Appendix Table 9, we split the sample according to whether the respondent belongs to the labor force or not. ${ }^{35}$ We find that the estimate of the marginal effect of education is systematically larger for those who belong to the labor force than for those who do not. This evidence confirms the above labor market interpretation of the marginal effect of education. In addition, the impact of education on legalization attitudes is positive and significant for individuals out of the labor force as well. Thus, our results are also consistent with a noneconomic interpretation of the effect of education, according to which the education variable is to some extent capturing the cultural openness of the respondent (see, for example, Hainmueller and Hiscox 2007). Thus, both noneconomic and labor market considerations shape the impact of education on public opinion on the Senate plan.

The impact of household income has been used in the literature to proxy for the perceived effect that immigration has on natives through the welfare state channel (Hanson et al. 2007; Hanson 2005; Facchini and Mayda 2009). In the presence of a redistributive welfare state, the positive coefficient on individual income suggests that respondents perceive the legalization provision contained in the Senate plan as bringing about an increase in the welfare state burden created by illegal immigrants, which is viewed negatively by both rich and poor natives, but by the poor even more than by the rich (given that the poor are the ones who are more adversely impacted by the reduction of public services). ${ }^{36}$ 


\section{Robustness checks}

In this section, we perform two sets of robustness checks on our baseline results. First, we carry out a series of falsification exercises on the role played by Lou Dobbs' $\mathrm{CNN}$ on migration attitudes, by looking at questions that tap into other policy preferences. Second, we introduce further controls at the individual and local levels to better deal with ideological self-selection into TV channels and, more generally, with omitted variable bias.

\subsection{Placebo tests on the Lou Dobbs effect}

We are concerned that individual-level unobservables might drive the negative correlation we find between $\mathrm{CNN}$ viewership and the probability of supporting the more lenient Senate plan. To deal with this issue, we exploit the richness of the CCES data, which contains several additional questions tapping into the preferences of individuals on other policy issues. The idea is to assess whether the similarity of $\mathrm{CNN}$ and Fox News viewers' opinions is confined only to immigration policy or whether it is a broader phenomenon.

To this end, we focus on answers to three additional questions and replicate specifications (1) and (2) from Table 3 using them as dependent variables. First, we look at opinions on an increase in the mandatory minimum wage. ${ }^{37}$

We create a pro_minimum_wage dummy, which equals 1 if the individual would favor an increase in the minimum wage and 0 otherwise. Second, we consider a question on whether the Iraq war was a mistake. ${ }^{38}$ Again, we construct a iraq_mistake dummy which takes a value of 1 if the respondent believes that the war was a mistake and 0 otherwise. Finally, we also look at a question on the desirability of a trade policy measure, i.e., participation of the USA in the Central America Free Trade Agreement (CAFTA) agreement. ${ }^{39}$ In particular, we create an anti_CAFTA dummy variable, which takes a value of 1 if the respondent opposes the agreement and 0 otherwise.

The results of the exercise are displayed in Table 5, which is divided in three parts, one for each of the three questions. The comparison of the estimated coefficients on the TV channel dummies between the two specifications in each subgroup-controlling and not controlling for ideology and party identification-allows us to assess the extent of ideological self-selection. Consider for instance the attitudes of Fox News viewers on the minimum wage and the Iraq war. When not controlling for ideology (columns [1] and [3]), these individuals are, respectively, 44 and 34\% less likely to support an increase in the minimum wage and to think that the Iraq war was a mistake, as compared to the excluded category of CBS viewers. Controlling instead for ideology and party id, these effects shrink to, respectively, 21 and $10 \%$. This evidence corresponds to what we have already found for illegal immigration.

On the other side of the political spectrum, we find an opposite pattern for PBS viewers, which again parallels our results regarding immigration attitudes. Finally, when looking at these three issues, $\mathrm{CNN}$ viewers appear broadly similar to PBS viewers, as they are (i) more favorable to an increase in the minimum wage, (ii) more likely to consider the Iraq war a mistake, and (iii) more likely to oppose the CAFTA agreement, as compared to the baseline category of CBS viewers (Table 5, columns [1], [3], and [5]). Moreover, when controlling for self-reported ideology and party id, the estimated marginal effects for $\mathrm{CNN}$ viewers similarly shrink in magnitude. ${ }^{40}$ 
Table 5 Robustness checks and placebo tests on other attitudinal variables

\begin{tabular}{|c|c|c|c|c|c|c|}
\hline \multirow{2}{*}{$\begin{array}{l}\text { Dependent variable } \\
\text { Estimation method }\end{array}$} & \multicolumn{2}{|c|}{ Pro_minimum_wage dummy } & \multicolumn{2}{|c|}{ Iraq_war_a_mistake dummy } & \multicolumn{2}{|c|}{ Anti_CAFTA dummy } \\
\hline & $\begin{array}{c}\text { Probit } \\
\text { [1] }\end{array}$ & $\begin{array}{c}\text { Probit } \\
\text { [2] }\end{array}$ & $\begin{array}{c}\text { Probit } \\
{[3]}\end{array}$ & $\begin{array}{c}\text { Probit } \\
{[4]}\end{array}$ & $\begin{array}{c}\text { Probit } \\
{[5]}\end{array}$ & $\begin{array}{c}\text { Probit } \\
{[6]}\end{array}$ \\
\hline Age & $\begin{array}{l}0.001 \\
{[0.001]}\end{array}$ & $\begin{array}{l}0.006^{c} \\
{[0.001]}\end{array}$ & $\begin{array}{l}-0.010^{c} \\
{[0.002]}\end{array}$ & $\begin{array}{l}-0.003 \\
{[0.002]}\end{array}$ & $\begin{array}{l}0.020^{c} \\
{[0.001]}\end{array}$ & $\begin{array}{l}0.021^{c} \\
{[0.001]}\end{array}$ \\
\hline Age squared & $\begin{array}{l}-0.000^{b} \\
{[0.000]}\end{array}$ & $\begin{array}{l}-0.000^{c} \\
{[0.000]}\end{array}$ & $\begin{array}{l}0.000^{c} \\
{[0.000]}\end{array}$ & $\begin{array}{l}0.000^{\mathrm{b}} \\
{[0.000]}\end{array}$ & $\begin{array}{l}-0.000^{c} \\
{[0.000]}\end{array}$ & $\begin{array}{l}-0.000^{c} \\
{[0.000]}\end{array}$ \\
\hline Female dummy & $\begin{array}{l}0.095^{c} \\
{[0.005]}\end{array}$ & $\begin{array}{l}0.066^{c} \\
{[0.005]}\end{array}$ & $\begin{array}{l}0.034^{c} \\
{[0.008]}\end{array}$ & $\begin{array}{l}-0.045^{c} \\
{[0.010]}\end{array}$ & $\begin{array}{l}0.083^{c} \\
{[0.009]}\end{array}$ & $\begin{array}{l}0.075^{c} \\
{[0.009]}\end{array}$ \\
\hline Black dummy & $\begin{array}{l}0.157^{c} \\
{[0.009]}\end{array}$ & $\begin{array}{l}0.096^{c} \\
{[0.008]}\end{array}$ & $\begin{array}{l}0.291^{c} \\
{[0.022]}\end{array}$ & $\begin{array}{l}0.161^{c} \\
{[0.024]}\end{array}$ & $\begin{array}{l}0.043^{c} \\
{[0.015]}\end{array}$ & $\begin{array}{l}0.016 \\
{[0.014]}\end{array}$ \\
\hline Latino dummy & $\begin{array}{l}0.061^{c} \\
{[0.007]}\end{array}$ & $\begin{array}{l}0.048^{c} \\
{[0.007]}\end{array}$ & $\begin{array}{l}0.054^{b} \\
{[0.021]}\end{array}$ & $\begin{array}{l}0.006 \\
{[0.023]}\end{array}$ & $\begin{array}{l}-0.071^{c} \\
{[0.016]}\end{array}$ & $\begin{array}{l}-0.082^{c} \\
{[0.016]}\end{array}$ \\
\hline Immigrant origin & $\begin{array}{l}0.011^{\mathrm{b}} \\
{[0.004]}\end{array}$ & $\begin{array}{l}-0.002 \\
{[0.004]}\end{array}$ & $\begin{array}{l}0.024^{c} \\
{[0.006]}\end{array}$ & $\begin{array}{l}-0.003 \\
{[0.009]}\end{array}$ & $\begin{array}{l}-0.018^{b} \\
{[0.008]}\end{array}$ & $\begin{array}{l}-0.020^{b} \\
{[0.008]}\end{array}$ \\
\hline Education & $\begin{array}{l}-0.010^{c} \\
{[0.002]}\end{array}$ & $\begin{array}{l}-0.020^{c} \\
{[0.002]}\end{array}$ & $\begin{array}{l}0.031^{c} \\
{[0.003]}\end{array}$ & $\begin{array}{l}0.025^{c} \\
{[0.003]}\end{array}$ & $\begin{array}{l}-0.044^{c} \\
{[0.004]}\end{array}$ & $\begin{array}{l}-0.045^{c} \\
{[0.004]}\end{array}$ \\
\hline Income & $\begin{array}{l}-0.011^{c} \\
{[0.001]}\end{array}$ & $\begin{array}{l}-0.007^{c} \\
{[0.001]}\end{array}$ & $\begin{array}{l}-0.008^{c} \\
{[0.002]}\end{array}$ & $\begin{array}{l}0.001 \\
{[0.001]}\end{array}$ & $\begin{array}{l}-0.014^{c} \\
{[0.001]}\end{array}$ & $\begin{array}{l}-0.012^{c} \\
{[0.001]}\end{array}$ \\
\hline $\begin{array}{l}\text { Conservative ideology } \\
\text { (100-point scale) }\end{array}$ & - & $\begin{array}{l}-0.005^{c} \\
{[0.000]}\end{array}$ & - & $\begin{array}{l}-0.010^{c} \\
{[0.000]}\end{array}$ & - & $\begin{array}{l}-0.001^{c} \\
{[0.000]}\end{array}$ \\
\hline Party id (3-point scale) & - & $\begin{array}{l}-0.072^{c} \\
{[0.004]}\end{array}$ & - & $\begin{array}{l}-0.243^{c} \\
{[0.009]}\end{array}$ & - & $\begin{array}{l}-0.044^{c} \\
{[0.007]}\end{array}$ \\
\hline ABC dummy & $\begin{array}{l}-0.092^{c} \\
{[0.022]}\end{array}$ & $\begin{array}{l}-0.061^{\mathrm{C}} \\
{[0.018]}\end{array}$ & $\begin{array}{l}-0.048^{c} \\
{[0.017]}\end{array}$ & $\begin{array}{l}-0.004 \\
{[0.016]}\end{array}$ & $\begin{array}{l}0.006 \\
{[0.022]}\end{array}$ & $\begin{array}{l}0.012 \\
{[0.023]}\end{array}$ \\
\hline CNN dummy & $\begin{array}{l}0.046^{c} \\
{[0.016]}\end{array}$ & $\begin{array}{l}0.013 \\
{[0.016]}\end{array}$ & $\begin{array}{l}0.169^{c} \\
{[0.014]}\end{array}$ & $\begin{array}{l}0.136^{c} \\
{[0.015]}\end{array}$ & $\begin{array}{l}0.101^{c} \\
{[0.018]}\end{array}$ & $\begin{array}{l}0.094^{c} \\
{[0.018]}\end{array}$ \\
\hline FOX News dummy & $\begin{array}{l}-0.442^{c} \\
{[0.020]}\end{array}$ & $\begin{array}{l}-0.207^{c} \\
{[0.020]}\end{array}$ & $\begin{array}{l}-0.588^{c} \\
{[0.011]}\end{array}$ & $\begin{array}{l}-0.337^{c} \\
{[0.016]}\end{array}$ & $\begin{array}{l}-0.104^{c} \\
{[0.023]}\end{array}$ & $\begin{array}{l}-0.048^{b} \\
{[0.022]}\end{array}$ \\
\hline PBS dummy & $\begin{array}{l}0.067^{c} \\
{[0.019]}\end{array}$ & $\begin{array}{l}0.002 \\
{[0.021]}\end{array}$ & $\begin{array}{l}0.260^{c} \\
{[0.016]}\end{array}$ & $\begin{array}{l}0.194^{c} \\
{[0.022]}\end{array}$ & $\begin{array}{l}0.097 c \\
{[0.022]}\end{array}$ & $\begin{array}{l}0.083^{c} \\
{[0.022]}\end{array}$ \\
\hline NBC dummy & $\begin{array}{l}-0.069^{c} \\
{[0.017]}\end{array}$ & $\begin{array}{l}-0.046^{c} \\
{[0.015]}\end{array}$ & $\begin{array}{l}-0.013 \\
{[0.016]}\end{array}$ & $\begin{array}{l}0.016 \\
{[0.018]}\end{array}$ & $\begin{array}{l}0.009 \\
{[0.017]}\end{array}$ & $\begin{array}{l}0.013 \\
{[0.017]}\end{array}$ \\
\hline MSNBC dummy & $\begin{array}{l}0.070^{C} \\
{[0.019]}\end{array}$ & $\begin{array}{l}0.017 \\
{[0.020]}\end{array}$ & $\begin{array}{l}0.221^{c} \\
{[0.015]}\end{array}$ & $\begin{array}{l}0.163^{c} \\
{[0.019]}\end{array}$ & $\begin{array}{l}0.109^{c} \\
{[0.016]}\end{array}$ & $\begin{array}{l}0.098^{c} \\
{[0.016]}\end{array}$ \\
\hline Other network dummy & $\begin{array}{l}-0.115^{c} \\
{[0.042]}\end{array}$ & $\begin{array}{l}-0.100^{c} \\
{[0.038]}\end{array}$ & $\begin{array}{l}-0.036 \\
{[0.038]}\end{array}$ & $\begin{array}{l}-0.002 \\
{[0.045]}\end{array}$ & $\begin{array}{l}0.047 \\
{[0.036]}\end{array}$ & $\begin{array}{l}0.052 \\
{[0.036]}\end{array}$ \\
\hline No evening news dummy & $\begin{array}{l}-0.299^{c} \\
{[0.020]}\end{array}$ & $\begin{array}{l}-0.194^{c} \\
{[0.018]}\end{array}$ & $\begin{array}{l}-0.252^{c} \\
{[0.018]}\end{array}$ & $\begin{array}{l}-0.121^{c} \\
{[0.020]}\end{array}$ & $\begin{array}{l}-0.051^{c} \\
{[0.018]}\end{array}$ & $\begin{array}{l}-0.026 \\
{[0.018]}\end{array}$ \\
\hline Pseudo R-squared & 0.18 & 0.31 & 0.26 & 0.53 & 0.06 & 0.07 \\
\hline Observations & 21,063 & 21,063 & 19,453 & 19,453 & 16,590 & 16,590 \\
\hline
\end{tabular}

The sample excludes all individuals who describe themselves as immigrants. In columns [1] and [2], the dependent variable is a dummy which equals 1 if the respondent would support an increase in the minimum wage and 0 otherwise. In column [3]-[4], the dependent variable is a dummy which equals 1 if the respondent thinks that the Iraq war was a mistake and 0 otherwise. In columns [5]-[6], the dependent variable is a dummy which equals 1 if the respondent would oppose the Central America Free Trade Agreement (CAFTA) and 0 otherwise. The panel contains the estimated marginal effect on the probability of supporting the said positions, given an increase in the value of the relevant regressor, holding all other regressors at their mean values. For each attitudinal variable, socio-economic and ideology controls are those included in regressions [1] and [2], respectively, in Table 3

a Significant at $1 \%$;

${ }^{\text {b }}$ significant at $5 \%$

${ }^{c}$ significant at $1 \%$

In Section 5.1, we correlated the implied ideological position of each media channel with the estimated effect on migration attitudes. From this point of view, Fig. 1 highlighted the peculiar case of CNN, a comparatively liberal TV channel with a negative effect on 
the propensity to support the more lenient Senate plan on illegal immigration. In Figs. 2, 3 and 4, we replicate the design of Fig. 1 but we focus on these three additional policy questions. More precisely, in Fig. 2, we plot-for each TV channel-the estimated marginal effect on the propensity to support an increase in the minimum wage against its overall ideological position. The former is taken from column [2] in Table 5. The latter is a measure of conservative ideology and is calculated as the difference in the estimated marginal effect of each channel dummy between specification [1] and specification [2], divided by the estimated correlation between the ideology score and minimum wage attitudes. We proceed in a similar fashion for the Iraq war (Fig. 3) and CAFTA questions (Fig. 4).

These three figures show the presence of a strongly negative and significant correlation between the estimated ideological position of each TV channel and its implied effect on viewers' opinion. Most importantly-and differently from Fig. 1-CNN does not appear to be an outlier at all, as it looks like a liberal media outlet with liberal effects on attitudes. In other words, we reject the alternative hypothesis that $\mathrm{CNN}$ viewers hold less liberal views on illegal immigration simply because they happen to be less liberal across the board.

\subsection{Additional controls}

The CCES survey contains a host of questions that allow us to further investigate the lifestyle and ideological position of the respondent. Moreover, by matching the CCES data with county-level information, we can better control for the politically relevant features of the local environment where the respondent lives. In Table 6, we check the robustness for our baseline results to controlling for these potentially confounding factors.

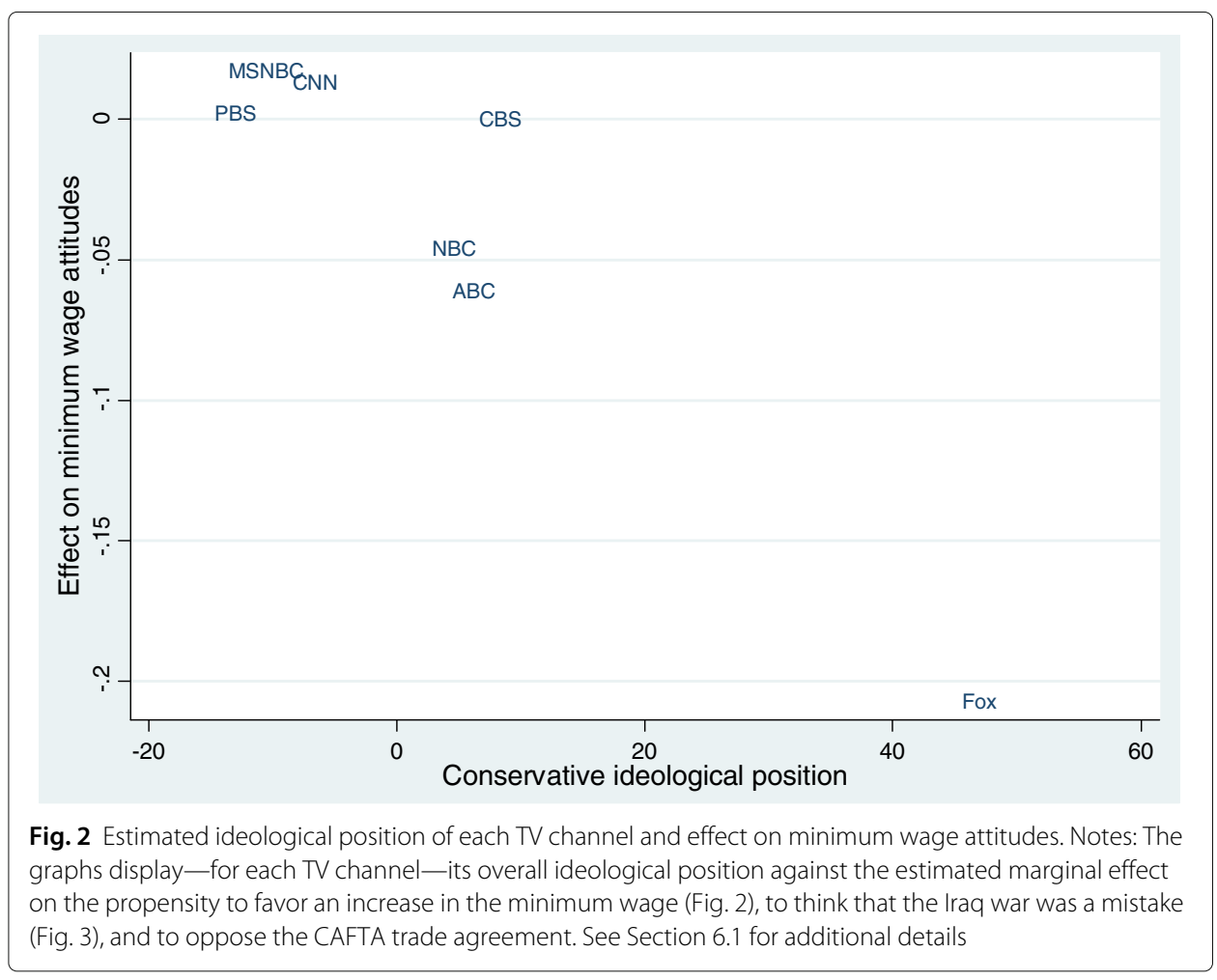



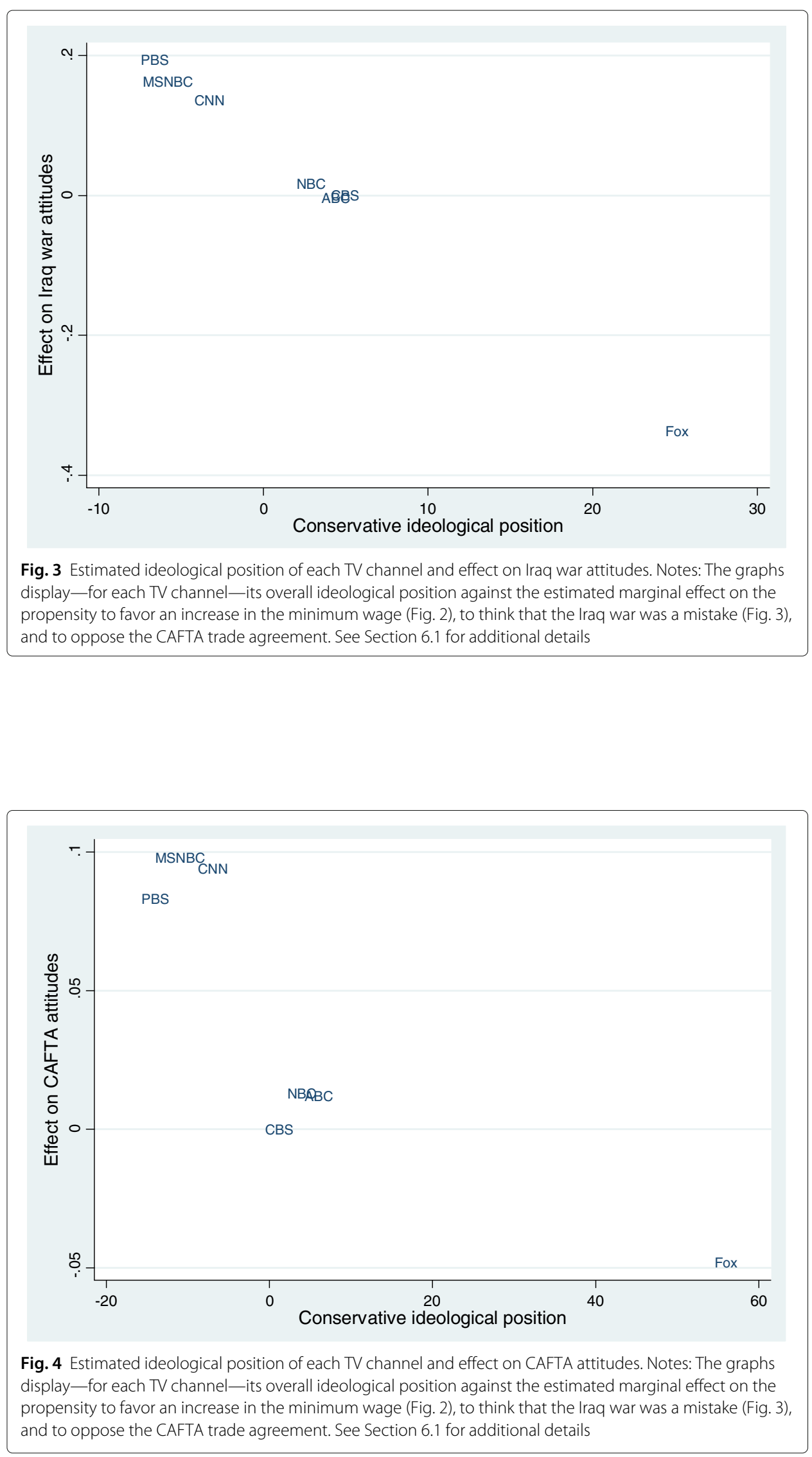
Table 6 Robustness checks

\begin{tabular}{|c|c|c|c|c|c|c|}
\hline \multirow{3}{*}{$\begin{array}{l}\text { Dependent variable } \\
\text { Estimation method }\end{array}$} & \multicolumn{6}{|c|}{ Pro_lenient_plan dummy } \\
\hline & Probit & Probit & Probit & Probit & Probit & Probit \\
\hline & {$[1]$} & {$[2]$} & {$[3]$} & {$[4]$} & {$[5]$} & {$[6]$} \\
\hline \multirow[t]{2}{*}{ Pickup truck dummy } & $-0.055^{c}$ & $-0.052^{c}$ & $-0.051^{c}$ & $-0.053^{c}$ & $-0.051^{c}$ & $-0.052^{c}$ \\
\hline & {$[0.009]$} & {$[0.009]$} & {$[0.009]$} & {$[0.010]$} & {$[0.010]$} & {$[0.010]$} \\
\hline \multirow[t]{2}{*}{ Protestant dummy } & - & $-0.065^{c}$ & $-0.058^{c}$ & - & $-0.046^{c}$ & $-0.040^{b}$ \\
\hline & & {$[0.015]$} & {$[0.016]$} & & {$[0.017]$} & {$[0.018]$} \\
\hline \multirow[t]{2}{*}{ Catholic dummy } & - & $-0.061^{c}$ & $-0.050^{c}$ & - & $-0.043^{c}$ & $-0.035^{b}$ \\
\hline & & {$[0.014]$} & {$[0.014]$} & & {$[0.015]$} & {$[0.016]$} \\
\hline \multirow[t]{2}{*}{ Jewish dummy } & - & -0.014 & -0.012 & - & 0.011 & 0.009 \\
\hline & & {$[0.029]$} & {$[0.031]$} & & {$[0.034]$} & {$[0.036]$} \\
\hline \multirow[t]{2}{*}{ Muslim dummy } & - & -0.001 & 0.002 & - & 0.157 & 0.193 \\
\hline & & {$[0.067]$} & {$[0.072]$} & & {$[0.127]$} & {$[0.137]$} \\
\hline \multirow[t]{2}{*}{ Other religion dummy } & - & -0.003 & 0.002 & - & -0.012 & -0.015 \\
\hline & & {$[0.017]$} & {$[0.018]$} & & {$[0.020]$} & {$[0.021]$} \\
\hline \multirow[t]{2}{*}{ Other Christian religion dummy } & - & $-0.077^{c}$ & $-0.069^{c}$ & - & $-0.051^{c}$ & $-0.044^{b}$ \\
\hline & & {$[0.018]$} & {$[0.019]$} & & {$[0.020]$} & {$[0.021]$} \\
\hline \multirow[t]{2}{*}{ Church attendance } & - & $0.026^{c}$ & $0.025^{c}$ & - & $0.019^{c}$ & $0.017^{c}$ \\
\hline & & {$[0.004]$} & {$[0.004]$} & & {$[0.004]$} & {$[0.004]$} \\
\hline \multirow[t]{2}{*}{ Importance of religion } & - & -0.006 & -0.012 & - & 0.012 & 0.009 \\
\hline & & {$[0.012]$} & {$[0.012]$} & & {$[0.012]$} & {$[0.013]$} \\
\hline \multirow[t]{2}{*}{ ABC dummy } & $-0.034^{b}$ & $-0.032^{b}$ & $-0.038^{b}$ & - & - & - \\
\hline & {$[0.014]$} & {$[0.015]$} & {$[0.015]$} & & & \\
\hline \multirow[t]{2}{*}{ CNN dummy } & $-0.089^{c}$ & $-0.091^{c}$ & $-0.095^{c}$ & - & - & - \\
\hline & {$[0.017]$} & {$[0.017]$} & {$[0.018]$} & & & \\
\hline \multirow[t]{2}{*}{ FOX News dummy } & $-0.094^{c}$ & $-0.091^{c}$ & $-0.098^{c}$ & - & - & - \\
\hline & {$[0.015]$} & {$[0.015]$} & {$[0.015]$} & & & \\
\hline \multirow[t]{2}{*}{ PBS dummy } & $0.139^{c}$ & $0.131^{c}$ & $0.123^{c}$ & - & - & - \\
\hline & {$[0.023]$} & {$[0.022]$} & {$[0.023]$} & & & \\
\hline \multirow[t]{2}{*}{ NBC dummy } & -0.001 & 0.002 & -0.005 & - & - & - \\
\hline & {$[0.016]$} & {$[0.017]$} & {$[0.017]$} & & & \\
\hline \multirow[t]{2}{*}{ MSNBC dummy } & -0.021 & -0.017 & -0.019 & - & - & - \\
\hline & {$[0.021]$} & {$[0.021]$} & {$[0.022]$} & & & \\
\hline \multirow[t]{2}{*}{ Other network dummy } & 0.008 & 0.015 & 0.007 & - & - & - \\
\hline & {$[0.030]$} & {$[0.030]$} & {$[0.029]$} & & & \\
\hline \multirow[t]{2}{*}{ No evening news dummy } & $-0.040^{\mathrm{b}}$ & $-0.043^{c}$ & $-0.050^{c}$ & - & - & - \\
\hline & {$[0.017]$} & {$[0.016]$} & {$[0.017]$} & & & \\
\hline \multirow{2}{*}{$\begin{array}{l}\text { Count of stories on illegal immigration } \\
\text { on favorite broadcast }\end{array}$} & - & - & - & $-0.001^{c}$ & $-0.001^{c}$ & $-0.001^{c}$ \\
\hline & & & & {$[0.000]$} & {$[0.000]$} & {$[0.000]$} \\
\hline \multirow{2}{*}{$\begin{array}{l}\text { Count of stories mentioning immigration, } \\
\text { on favorite broadcast }\end{array}$} & - & - & - & $-0.001^{c}$ & $-0.001^{c}$ & $-0.001^{c}$ \\
\hline & & & & {$[0.000]$} & {$[0.000]$} & {$[0.000]$} \\
\hline Population density (county level) & $0.026^{c}$ & $0.027^{c}$ & $0.025^{c}$ & $0.025^{c}$ & $0.022^{c}$ & $0.021^{c}$ \\
\hline & - & {$[0.007]$} & {$[0.005]$} & {$[0.006]$} & {$[0.007]$} & {$[0.005]$} \\
\hline Crime rate, 2004 (county level) & - & - & $0.009^{c}$ & - & - & $0.008^{c}$ \\
\hline & & & {$[0.002]$} & & & [0.003] \\
\hline Unemployment rate, 2005 (county level) & - & - & $-0.005^{\mathrm{a}}$ & - & - & -0.005 \\
\hline & & & {$[0.003]$} & & & {$[0.003]$} \\
\hline Fraction of illegal immigrants (state level) & $0.008^{c}$ & $0.008^{c}$ & $0.006^{\mathrm{a}}$ & $0.009^{c}$ & $0.009^{c}$ & $0.006^{\mathrm{a}}$ \\
\hline & {$[0.003]$} & {$[0.003]$} & {$[0.003]$} & {$[0.003]$} & {$[0.003]$} & {$[0.003]$} \\
\hline
\end{tabular}


Table 6 Robustness checks (Continued)

\begin{tabular}{|c|c|c|c|c|c|c|}
\hline \multirow[t]{2}{*}{ Fraction of legal immigrants (state level) } & $-0.002^{b}$ & $-0.002^{a}$ & -0.001 & $-0.002^{a}$ & $-0.002^{a}$ & -0.002 \\
\hline & {$[0.001]$} & {$[0.001]$} & {$[0.001]$} & {$[0.001]$} & {$[0.001]$} & {$[0.001]$} \\
\hline Socio-economic and ideology cont. & Yes & Yes & Yes & Yes & Yes & Yes \\
\hline Pseudo $R$-squared & 0.18 & 0.18 & 0.18 & 0.16 & 0.16 & 0.16 \\
\hline Observations & 20,357 & 19,728 & 18,466 & 13,615 & 13,157 & 12,305 \\
\hline
\end{tabular}

In column [1] of Table 6, we include the same variables as in column [3] of Table 3 plus a control for whether the respondent owns a pickup truck: as discussed in Section 4 , this variable might simultaneously capture whether the individual does not live in a city and something about his lifestyle. We find that owning a pickup truck is associated with a 5.5-percentage-point reduction in the probability to support the Senate plan.

As discussed by Guiso et al. (2003), individual attitudes might be systematically correlated with the type and intensity of religious beliefs being held. Regarding the specific topic of immigration, Guiso et al. (2003) show that individuals interviewed within the World Values Survey (WVS) are significantly more intolerant towards immigrants if they were raised religiously and they report to be currently religious, while being actively religious is not significantly correlated with immigration attitudes. Moreover, Guiso et al. (2003) show that Catholics, Protestants, and Muslims are more likely to be intolerant towards immigrants than agnostic individuals, while Buddhists display the opposite tendency.

In columns [2] and [3] of Table 6, we exploit the CCES questions tapping into the religious beliefs and habits of respondents. More specifically, we include dummy variables for the respondent declaring to be Protestant, Catholic, Jewish, Muslim, of another religion, or of another Christian religion, keeping as the omitted category those who declare not to have any religious preference. We also control for each individual's church attendance frequency and for the importance he/she attaches to religion in everyday life. Self-declared Protestants and Catholics are around 6 percentage points less likely to support the Senate plan on illegal immigration, as compared to individuals with no religious preference. The correlation is of the same sign and larger in magnitude (around 8 percentage points) for those who declare to belong to another Christian religion. The level of significance is $1 \%$ for all three marginal effects. On the other hand, the propensity to favor the more lenient plan on illegal immigration is significantly and positively correlated with church attendance. ${ }^{41}$ Finally, the religion importance dummy is not significantly correlated with the respondent's opinion on the illegal immigration plan.

From this point of view, our results are reasonably in line with those obtained by Guiso et al.: we similarly find that immigration attitudes are significantly more negative for Catholics and Protestants; however, we find no significant effect for Muslims. This could be due to the lower number of Muslims in the USA, as compared to the cross-country WVS sample. Moreover, differently from Guiso et al., we find that church attendance has 
a mitigating effect on negative immigration attitudes. Of course, one should handle this comparison with some further caution, since (i) our sample focuses on the USA; (ii) we are concerned with illegal immigration, rather than with the immigration phenomenon as a whole; and (iii) we use as the dependent variable a policy-related question, instead of a direct question about attitudes.

An additional concern regarding our results is the possibility that they are partially driven by omitted variables at the state or county level. In Table 3, we have already shown that our findings are robust to the inclusion of state and DMA fixed effects as well as to controlling for population density at the county level. In column [3] of Table 6, we further control for the county-specific 2004 crime rate and 2005 unemployment rate: the rationale for this is that individuals might be particularly sensitive to their economic and social environment when they are asked about a policy proposal regarding a potentially very contentious issue.

We find a positive, statistically significant and quantitatively non-negligible correlation between the county-level crime rate and the propensity to support the Senate plan: an additional crime event for every 100 inhabitants is associated with about a 1-percentagepoint increase in the probability of favoring the more lenient plan on immigration. Conditionally on all the caveats regarding the distinction between causation and correlation, this result is consistent with the hypothesis that individuals on average believe that an immigrant's illegal status is conducive to a higher propensity to criminal behavior and that legalization might help break this vicious link. On the other hand, we find no significant impact of the unemployment rate. It is also worthwhile to notice that, in columns [1] and [2], there is a mildly significant and negative relationship between the propensity to support the Senate plan and the state-specific fraction of legal immigrants. ${ }^{42}$ It is still the case that the fraction of illegal immigrants is positively and significantly correlated with the pro_lenient_plan dummy, mildly so in column [3].

In the second part of Table 6 (columns [4], [5], and [6]), we replicate the format of the first part but use the cardinal measure of immigration coverage (as already explored in the second part of Table 3). When doing so, we do not find significant departures from the results in Table 3 and-regarding the robustness checks themselves-from those displayed in the first part of Table 6.

\section{Conclusions}

In this paper, we have analyzed the determinants of public opinion on illegal immigration and, in particular, the role played by the media in shaping these attitudes. Our main results suggest that both economic and noneconomic drivers are important. We find that respondents are more favorable to the plan on illegal immigration introduced in the US Senate in 2006, the more skilled, more liberal, and richer they are. Furthermore, we find that individuals watching Fox and CNN evening news are substantially more likely to oppose the Senate plan than those who watch CBS. PBS viewers are instead more likely to support it.

Our paper thus provides strongly suggestive and robust evidence that the media do play an important role in shaping individual preferences on an important policy issue like illegal immigration. Still, to the extent that we do not have a clean natural experiment, our findings must be interpreted with caution. As we have repeatedly stressed in the paper, the crucial confounding factor is self-selection: individuals do choose to expose themselves 
to a media outlet, whose ideological position is close to theirs. Still, our analysis points out that $\mathrm{CNN}$ viewers, who according to our findings entertain liberal preferences, share opinions towards the Senate plan that are similar to those of FOX viewers, a much more conservative group, whereas they differ from them on a wide array of other issues. This finding is consistent with what we have named the "Lou Dobbs" effect: the CNN anchorman-who entertains a very negative position about illegal immigration-appears to have been able to influence his viewer's opinions on the legislation introduced in the US Senate, making them less supportive of a proposal that included a substantial legalization initiative. $^{43}$

\section{Endnotes}

${ }^{1} \mathrm{~A}$ few papers have focused on questions related to illegal immigration in specific regions. Hood III and Morris (2000), Newton (2000), and Tam and Cain (2001), for instance, have looked at the determinants of support for proposition 187 in California, which limited the access enjoyed by illegal immigrants to a series of welfare state benefits.

${ }^{2}$ http://cces.gov.harvard.edu/data.

${ }^{3}$ Lou Dobbs, the anchorman and managing editor of $\mathrm{CNN}$ evening news at the time of the survey (Lou Dobbs Tonight), has been very vocal about the costs of illegal immigration and a staunch opponent of the Senate plan.

${ }^{4}$ The estimates reported above are based on regressions which control for self-reported ideology and party identification.

${ }^{5}$ For direct evidence on the effects of legalization on undocumented immigrants' job perspectives, see Kossoudji and Cobb-Clark (2002) and Orrenius and Zavodny (2007).

${ }^{6}$ See Espenshade and Hempstead (1996) and Hainmueller and Hiscox (2007) for an alternative interpretation of the empirical evidence on the impact of skill.

${ }^{7}$ Experimental evidence, such as that provided by Iyengar et al. (1982), lends the strongest support to the presence of a causal link going from the media to the public agenda.

${ }^{8}$ See Krosnick and Miller (1996) for a review of this literature. For lab experiments on priming, see Iyengar and Kinder (1987) and Valentino et al. (2002), with the latter specifically focused on racial attributes. See also Lenz (2009) for a critical evaluation of the concept of priming.

${ }^{9}$ Specifically on migration, Brader et al. (2008) investigate-within a survey experiment-how the framing of the issue affects individual attitudes. They find that a Latino frame, when coupled with some emphasis on the costs of immigration, is especially conducive to negative feelings towards immigration through the "anxiety" channel.

${ }^{10}$ From this point of view, these contributions build on the empirical literature which aims at measuring the ideological position of media outlets. See, e.g., Groseclose and Milyo (2005), Puglisi (2011), Lott Jr and Hassett (2004), Gentzkow and Shapiro (2010), Larcinese et al. (2011), and Puglisi and Snyder Jr (2011).

${ }^{11}$ Chiang and Knight (2011) use interview data to assess the effect of a presidential candidate's endorsement by a newspaper on its readers' propensity to vote for that candidate. Exploiting the difference between individuals being interviewed before or after the publication of the endorsement, they show that only surprising endorsements, i.e., those that depart from the expected ideological stance of the newspaper, affect voting behavior. 
${ }^{12}$ Larcinese et al. (2011) have found evidence for this type of behavior looking at the differential coverage of good vs. bad economic news as a function of the political affiliation of the incumbent president.

${ }^{13}$ In fact, as emphasized by McCombs (2002) and Weaver (2007), the concepts of priming and framing do overlap.

${ }^{14}$ Citrin et al. (1997), using the 1992 and 1994 ANES surveys, find instead only limited support for the role played by economic drivers.

${ }^{15}$ See Hanson (2006) for more details.

${ }^{16}$ For instance, $26 \%$ of the workers in landscaping services and $20 \%$ of those in meat/poultry packing are unauthorized. According to Passel (2005), in ten industries, illegal immigrants represent more than $10 \%$ of the overall labor force.

${ }^{17}$ For additional methodological details, see Ansolabehere and Schaffner (2010) and http://cces.gov.harvard.edu/data.

${ }^{18}$ We have analyzed the robustness of our findings when we include the "don't know" observations in, alternatively, the pro-migration category or in the anti-migration category of the dependent variable. The results are available upon request, and in both cases, the estimates are remarkably similar to those we derive excluding the "don't know" observations . Most likely, this is due to the relatively small number of "don't know" observations and suggests that excluding them from the analysis is unlikely to be an issue.

${ }^{19}$ The exact wording is as follows: "Which network do you watch most frequently for national evening news?"

${ }^{20}$ There is an additional category for those who decline to answer. We exclude them from the analysis, since it is unclear whether they are drawn disproportionately from the highest or the lowest income bracket.

${ }^{21}$ ICPSR Study No. 20660: see http://www.icpsr.umich.edu/cocoon/ICPSR/STUDY/ 20660.xml.

${ }^{22}$ See http://pewhispanic.org/reports/foreignborn/.

${ }^{23}$ On the other hand, in the second question, individuals are asked about the Senate vs. House plans. We have decided not to use the second question as our main dependent variable since it is asked to a substantially smaller number of respondents.

${ }^{24}$ The most important differences are that, in the regressions using the second question, the Black dummy variable is often negative and significant when we control for ideology; in addition, the fraction of illegal immigrants at the state level does not have a significant effect.

${ }^{25}$ DMAs identify the different TV cable markets in the USA; they are named after the main city (or cities) in each area. See DellaVigna and Kaplan (2007) for more details.

${ }^{26}$ This result is in fact consistent with the Groseclose and Milyo (2005) analysis of think tank quotes, which places Fox News' Special Report with Brit Hume significantly to the right with respect to CBS Evening News.

${ }^{27}$ See also Akdenizli et al. (2008).

${ }^{28}$ The excerpt is taken from Lou Dobbs Tonight, May 25, 2006.

${ }^{29}$ This replacement marginally goes in the direction of increasing the point estimates of the marginal effect of the Fox News dummy (i.e., reducing its absolute value) and decreasing the one on the CNN dummy (i.e., increasing its absolute value).

${ }^{30}$ In fact, when including $\mathrm{CNN}$, the relationship between the overall ideological position of each TV channel and its persuasive effect on immigration attitudes is negative 
and not far from statistical significance at the $10 \%$ level, while it is significant almost at the 5\% level when excluding CNN. One can also notice that the so-called Big Three, i.e., the oldest US networks ( $\mathrm{ABC}, \mathrm{CBS}$, and $\mathrm{NBC}$ ), are closely clustered in the scatter plot, while PBS, the publicly financed channel, displays the most liberal stance on both dimensions. In Section 6.1, we carry out a series of placebo experiments to illustrate how these findings are unique to the immigration question.

${ }^{31}$ A word of caution regarding Fox News: Since the transcripts for its evening news broadcast are not available, we instead look at those of the O'Reilly Factor.

${ }^{32}$ We thank Stefano Della Vigna for kindly sharing these data with us.

${ }^{33}$ The only exception is the coefficient on income in column 1, which is not significant. This is likely due to an omitted variable bias since, when we control for ideology in the following specifications, the coefficient becomes strongly significant.

${ }^{34}$ In general, the labor market competition hypothesis predicts that the level of individual skill should be positively correlated with pro-immigration preferences in countries where immigrants increase the labor market competition for unskilled natives (for example, when immigrants are unskilled) and negatively correlated in countries where immigrants increase the labor market competition for skilled natives (for example, when immigrants are skilled). See Figure 5 in the online Appendix.

${ }^{35}$ Notice that students are excluded from both subsamples.

${ }^{36}$ For a somewhat different point of view, see Camarota (2005).

${ }^{37}$ The exact wording of the CCES question is as follows: "As you may know, the federal minimum wage is currently $\$ 5.15$ an hour. Do you favor or oppose raising the minimum wage to $\$ 7.25$ an hour over the next two years, or not?"

${ }^{38}$ The exact wording of the question is as follows: "Looking back, do you think the United States did the right thing in taking military action against Iraq, or should the U.S. have stayed out?"

${ }^{39}$ The exact wording of the question is as follows: "This year Congress also debated a new free trade agreement that reduces barriers to trade between the U.S. and countries in Central America. Some politicians argue that the agreement allows America to better compete in the global economy and would create more stable democracies in Central America. Other politicians argue that it helps businesses to move jobs abroad where labor is cheaper and does not protect American producers [...] What do you think? If you were faced with this decision, would you vote for or against the trade agreement?"

${ }^{40}$ Interestingly, on these three issues, MSNBC viewers appear to be similar to the PBS ones, both in the size of the estimated coefficients and in the changes taking place when controlling for ideology.

${ }^{41}$ When distinguishing according to the religious faith of the respondent, further results-available upon request-show that the church attendance variable is statistically significant only for Protestants, Catholics, and individuals belonging to another Christian obedience.

${ }^{42}$ The relationship is no longer significant in column [3].

${ }^{43}$ The departure of Lou Dobbs from CNN in November 2009 can be interpreted as an ex post confirmation of his "heretic" position within the network. In fact, it came after a mounting wave of criticisms regarding his overall stance on the immigration issue and the extended coverage he devoted to the so-called birther conspiracy theory, i.e., Barack Obama's citizenship and legitimacy to run as presidential candidate. 


\section{Appendix}

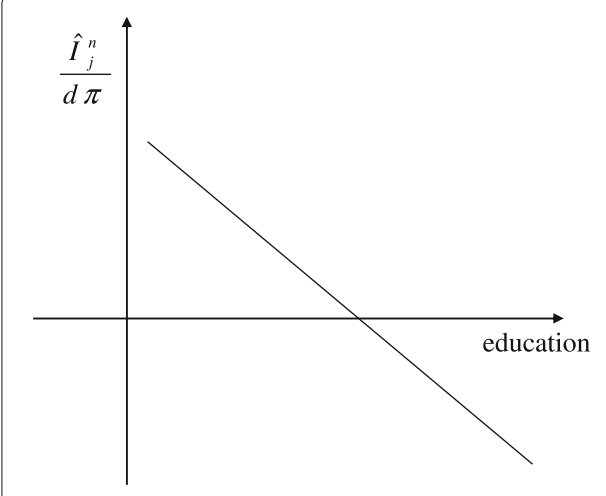

Skilled migration

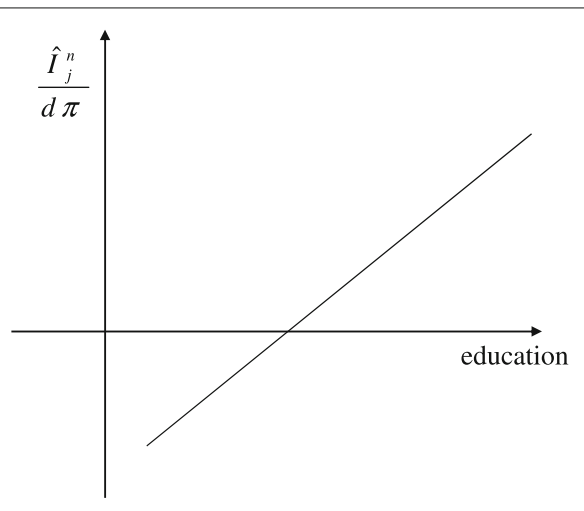

Unskilled migration

Fig. 5 Labor market effect. Notes: the graph shows the relationships between the respondent's education and the sensitivity of his/her net income to migration according to the labor market channel, as a function of wether immigration is relatively skilled or unskilled. $\frac{\hat{i}_{j}^{n}}{d \pi}$ represents the percentage change in individual income for a maginal change in $\pi$, the ratio of immigrants to natives

Table 7 Correlates of attitudes towards illegal immigration, baseline specification, question about the Senate vs. the House plan

\begin{tabular}{|c|c|c|c|c|c|c|c|}
\hline \multirow{2}{*}{$\begin{array}{l}\text { Dependent variable } \\
\text { Estimation method }\end{array}$} & \multicolumn{7}{|c|}{ Pro_lenient_plan2 dummy } \\
\hline & $\begin{array}{l}\text { Probit } \\
{[1]}\end{array}$ & $\begin{array}{l}\text { Probit } \\
\text { [2] }\end{array}$ & $\begin{array}{l}\text { Probit } \\
\text { [3] }\end{array}$ & $\begin{array}{l}\text { Probit } \\
{[4]}\end{array}$ & $\begin{array}{l}\text { Probit } \\
\text { [5] }\end{array}$ & $\begin{array}{l}\text { Probit } \\
\text { [6] }\end{array}$ & $\begin{array}{l}\text { Probit } \\
\text { [7] }\end{array}$ \\
\hline \multirow[t]{2}{*}{ Age } & $-0.018^{c}$ & $-0.013^{c}$ & $-0.013^{c}$ & $-0.013^{c}$ & $-0.013^{c}$ & $-0.011^{c}$ & $-0.012^{c}$ \\
\hline & {$[0.001]$} & {$[0.001]$} & {$[0.001]$} & {$[0.001]$} & {$[0.001]$} & {$[0.002]$} & {$[0.002]$} \\
\hline \multirow[t]{2}{*}{ Age squared } & $0.000^{c}$ & $0.000^{c}$ & $0.000^{c}$ & $0.000^{c}$ & $0.000^{c}$ & $0.000^{c}$ & $0.000^{c}$ \\
\hline & {$[0.000]$} & {$[0.000]$} & {$[0.000]$} & {$[0.000]$} & {$[0.000]$} & {$[0.000]$} & {$[0.000]$} \\
\hline \multirow[t]{2}{*}{ Female dummy } & $0.044^{c}$ & 0.005 & 0.002 & 0.003 & 0.002 & -0.002 & 0 \\
\hline & {$[0.011]$} & {$[0.012]$} & {$[0.012]$} & {$[0.012]$} & {$[0.013]$} & {$[0.012]$} & {$[0.011]$} \\
\hline \multirow[t]{2}{*}{ Black dummy } & 0.029 & -0.024 & -0.032 & -0.03 & -0.03 & -0.03 & -0.028 \\
\hline & {$[0.031]$} & {$[0.026]$} & {$[0.023]$} & {$[0.024]$} & {$[0.023]$} & {$[0.026]$} & {$[0.027]$} \\
\hline \multirow[t]{2}{*}{ Latino dummy } & $0.200^{c}$ & $0.171^{c}$ & $0.169^{c}$ & $0.165^{c}$ & $0.166^{c}$ & $0.139^{c}$ & $0.148^{c}$ \\
\hline & {$[0.016]$} & {$[0.019]$} & {$[0.020]$} & {$[0.021]$} & {$[0.023]$} & {$[0.021]$} & {$[0.022]$} \\
\hline \multirow[t]{2}{*}{ Immigrant origin } & $0.026^{c}$ & $0.019^{c}$ & $0.018^{c}$ & $0.019^{c}$ & $0.020^{c}$ & $0.031^{c}$ & $0.031^{c}$ \\
\hline & {$[0.007]$} & {$[0.007]$} & {$[0.006]$} & {$[0.006]$} & {$[0.006]$} & {$[0.007]$} & {$[0.007]$} \\
\hline \multirow[t]{2}{*}{ Education } & $0.045^{c}$ & $0.041^{c}$ & $0.042^{c}$ & $0.042^{c}$ & $0.041^{c}$ & $0.041^{c}$ & $0.037^{c}$ \\
\hline & {$[0.005]$} & {$[0.005]$} & {$[0.005]$} & {$[0.005]$} & {$[0.005]$} & {$[0.005]$} & {$[0.005]$} \\
\hline \multirow[t]{2}{*}{ Income } & 0.001 & $0.005^{b}$ & $0.004^{b}$ & $0.004^{b}$ & $0.004^{b}$ & $0.006^{c}$ & $0.007^{c}$ \\
\hline & {$[0.002]$} & {$[0.002]$} & {$[0.002]$} & {$[0.002]$} & {$[0.002]$} & {$[0.002]$} & {$[0.002]$} \\
\hline Conservative ideology & - & $-0.006^{c}$ & $-0.005^{c}$ & $-0.005^{c}$ & $-0.006^{c}$ & $-0.005^{c}$ & $-0.005^{c}$ \\
\hline (100-point scale) & {$[0.000]$} & {$[0.000]$} & {$[0.000]$} & {$[0.000]$} & {$[0.000]$} & {$[0.000]$} & \\
\hline
\end{tabular}


Table 7 Correlates of attitudes towards illegal immigration, baseline specification, question about the Senate vs. the House plan (Continued)

\begin{tabular}{|c|c|c|c|c|c|c|c|}
\hline Party id (3-point scale) & - & $\begin{array}{l}-0.054^{c} \\
{[0.008]}\end{array}$ & - & - & - & - & - \\
\hline Party id (7-point scale) & $\begin{array}{l}- \\
{[0.003]}\end{array}$ & $\begin{array}{l}- \\
{[0.003]}\end{array}$ & $\begin{array}{l}-0.029^{c} \\
{[0.003]}\end{array}$ & $\begin{array}{l}-0.030^{c} \\
{[0.005]}\end{array}$ & $\begin{array}{l}-0.029^{c} \\
{[0.005]}\end{array}$ & $-0.035^{c}$ & $-0.029^{c}$ \\
\hline ABC dummy & $\begin{array}{l}-0.039 \\
{[0.024]}\end{array}$ & $\begin{array}{l}0.007 \\
{[0.028]}\end{array}$ & $\begin{array}{l}-0.005 \\
{[0.028]}\end{array}$ & $\begin{array}{l}-0.007 \\
{[0.027]}\end{array}$ & $\begin{array}{l}-0.003 \\
{[0.030]}\end{array}$ & - & - \\
\hline CNN dummy & $\begin{array}{l}-0.061^{c} \\
{[0.019]}\end{array}$ & $\begin{array}{l}-0.062^{c} \\
{[0.019]}\end{array}$ & $\begin{array}{l}-0.074^{c} \\
{[0.018]}\end{array}$ & $\begin{array}{l}-0.073^{c} \\
{[0.018]}\end{array}$ & $\begin{array}{l}-0.071^{c} \\
{[0.019]}\end{array}$ & - & - \\
\hline FOX News dummy & $\begin{array}{l}-0.292^{c} \\
{[0.014]}\end{array}$ & $\begin{array}{l}-0.114^{c} \\
{[0.020]}\end{array}$ & $\begin{array}{l}-0.109^{c} \\
{[0.020]}\end{array}$ & $\begin{array}{l}-0.109^{c} \\
{[0.020]}\end{array}$ & $\begin{array}{l}-0.107^{c} \\
{[0.021]}\end{array}$ & - & - \\
\hline PBS dummy & $\begin{array}{l}0.189^{c} \\
{[0.031]}\end{array}$ & $\begin{array}{l}0.131^{c} \\
{[0.032]}\end{array}$ & $\begin{array}{l}0.115^{c} \\
{[0.030]}\end{array}$ & $\begin{array}{l}0.113^{c} \\
{[0.029]}\end{array}$ & $\begin{array}{l}0.125^{c} \\
{[0.033]}\end{array}$ & - & - \\
\hline NBC dummy & $\begin{array}{l}-0.016 \\
{[0.017]}\end{array}$ & $\begin{array}{l}0.02 \\
{[0.020]}\end{array}$ & $\begin{array}{l}0.01 \\
{[0.018]}\end{array}$ & $\begin{array}{l}0.011 \\
{[0.019]}\end{array}$ & $\begin{array}{l}0.018 \\
{[0.020]}\end{array}$ & - & - \\
\hline MSNBC dummy & $\begin{array}{l}-0.007 \\
{[0.027]}\end{array}$ & $\begin{array}{l}-0.031 \\
{[0.022]}\end{array}$ & $\begin{array}{l}-0.040^{\mathrm{a}} \\
{[0.022]}\end{array}$ & $\begin{array}{l}-0.040^{\mathrm{a}} \\
{[0.023]}\end{array}$ & $\begin{array}{l}-0.038 \\
{[0.024]}\end{array}$ & - & - \\
\hline Other network dummy & $\begin{array}{l}0.014 \\
{[0.050]}\end{array}$ & $\begin{array}{l}0.041 \\
{[0.050]}\end{array}$ & $\begin{array}{l}0.028 \\
{[0.050]}\end{array}$ & $\begin{array}{l}0.026 \\
{[0.049]}\end{array}$ & $\begin{array}{l}0.031 \\
{[0.054]}\end{array}$ & - & - \\
\hline No evening news dummy & $\begin{array}{l}-0.077^{c} \\
{[0.021]}\end{array}$ & $\begin{array}{l}0.009 \\
{[0.023]}\end{array}$ & $\begin{array}{l}0.003 \\
{[0.022]}\end{array}$ & $\begin{array}{l}0.003 \\
{[0.022]}\end{array}$ & $\begin{array}{l}0.007 \\
{[0.024]}\end{array}$ & - & - \\
\hline $\begin{array}{l}\text { Count of stories on illegal } \\
\text { immigration on the favorite news } \\
\text { broadcast }\end{array}$ & - & - & - & - & - & - & $\begin{array}{l}-0.001^{c} \\
{[0.000]}\end{array}$ \\
\hline $\begin{array}{l}\text { Count of stories mentioning } \\
\text { immigration, but not the illegal } \\
\text { one, on favorite broadcast }\end{array}$ & - & - & - & - & - & - & $\begin{array}{l}-0.001^{c} \\
{[0.000]}\end{array}$ \\
\hline Population density (county level) & $\begin{array}{l}- \\
{[0.007]}\end{array}$ & $\begin{array}{l}- \\
{[0.006]}\end{array}$ & $\begin{array}{l}0.014^{b} \\
{[0.005]}\end{array}$ & $\begin{array}{l}0.013^{b} \\
{[0.008]}\end{array}$ & $\begin{array}{l}0.022^{c} \\
{[0.008]}\end{array}$ & 0.006 & 0.011 \\
\hline $\begin{array}{l}\text { Fraction of legal immigrants } \\
\text { (state level) }\end{array}$ & - & - & $\begin{array}{l}0.001 \\
{[0.001]}\end{array}$ & - & - & $\begin{array}{l}0.001 \\
{[0.001]}\end{array}$ & $\begin{array}{l}0.001 \\
{[0.001]}\end{array}$ \\
\hline $\begin{array}{l}\text { State fixed effects } \\
\text { DMA fixed effects } \\
\text { Pseudo R-squared } \\
\text { Observations }\end{array}$ & $\begin{array}{l}\text { No } \\
\text { No } \\
0.14 \\
8430\end{array}$ & $\begin{array}{l}\text { No } \\
\text { No } \\
0.25 \\
8430\end{array}$ & $\begin{array}{l}\text { No } \\
\text { No } \\
0.25 \\
8879\end{array}$ & $\begin{array}{l}\text { Yes } \\
\text { No } \\
0.26 \\
8877\end{array}$ & $\begin{array}{l}\text { No } \\
\text { Yes } \\
0.27 \\
8801\end{array}$ & $\begin{array}{l}\text { No } \\
\text { No } \\
0.22 \\
5871\end{array}$ & $\begin{array}{l}\text { No } \\
\text { No } \\
0.24 \\
5871\end{array}$ \\
\hline
\end{tabular}

Table 8 Media coverage of immigration on evening news broadcasts, 2006

\begin{tabular}{lllllll}
\hline & \multicolumn{7}{l}{ Channels } \\
\cline { 2 - 7 } Search terms & ABC & CBS & CNN & FOX & PBS & NBC \\
\hline (A): "immigrants" OR "immigration" & 178 & 65 & 215 & 261 & 60 & 154 \\
(B): "illegal immigrants" OR "illegal immigration" & 90 & 42 & 195 & 142 & 33 & 73 \\
Difference: (A) - (B) & 88 & 23 & 20 & 119 & 27 & 81 \\
\hline
\end{tabular}

number of articles with the specified search terms, from January to October 2006. In the case of Fox News, searches are from the O'Reilly Factor. Source: Dow Jones Factiva archive 


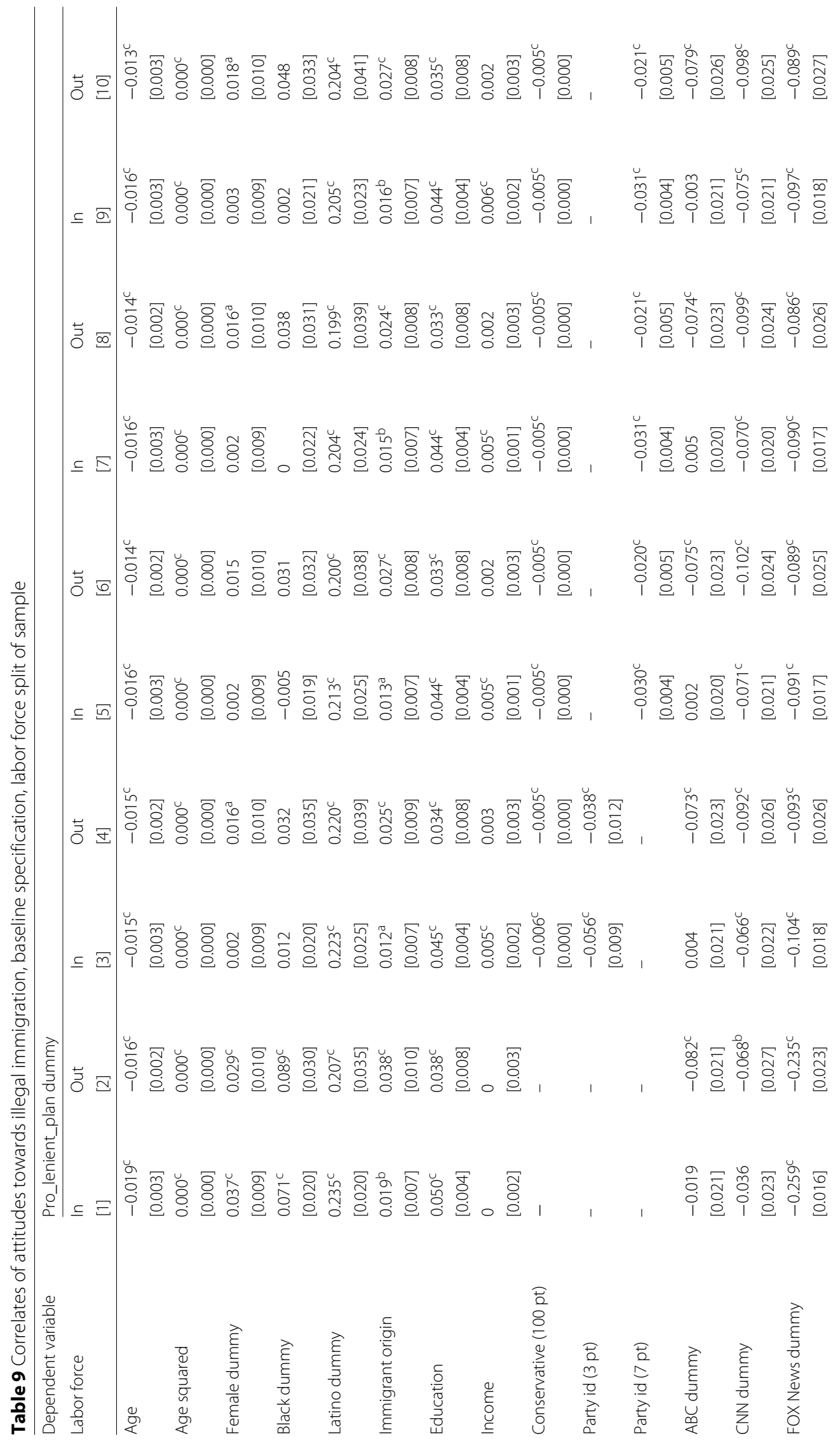




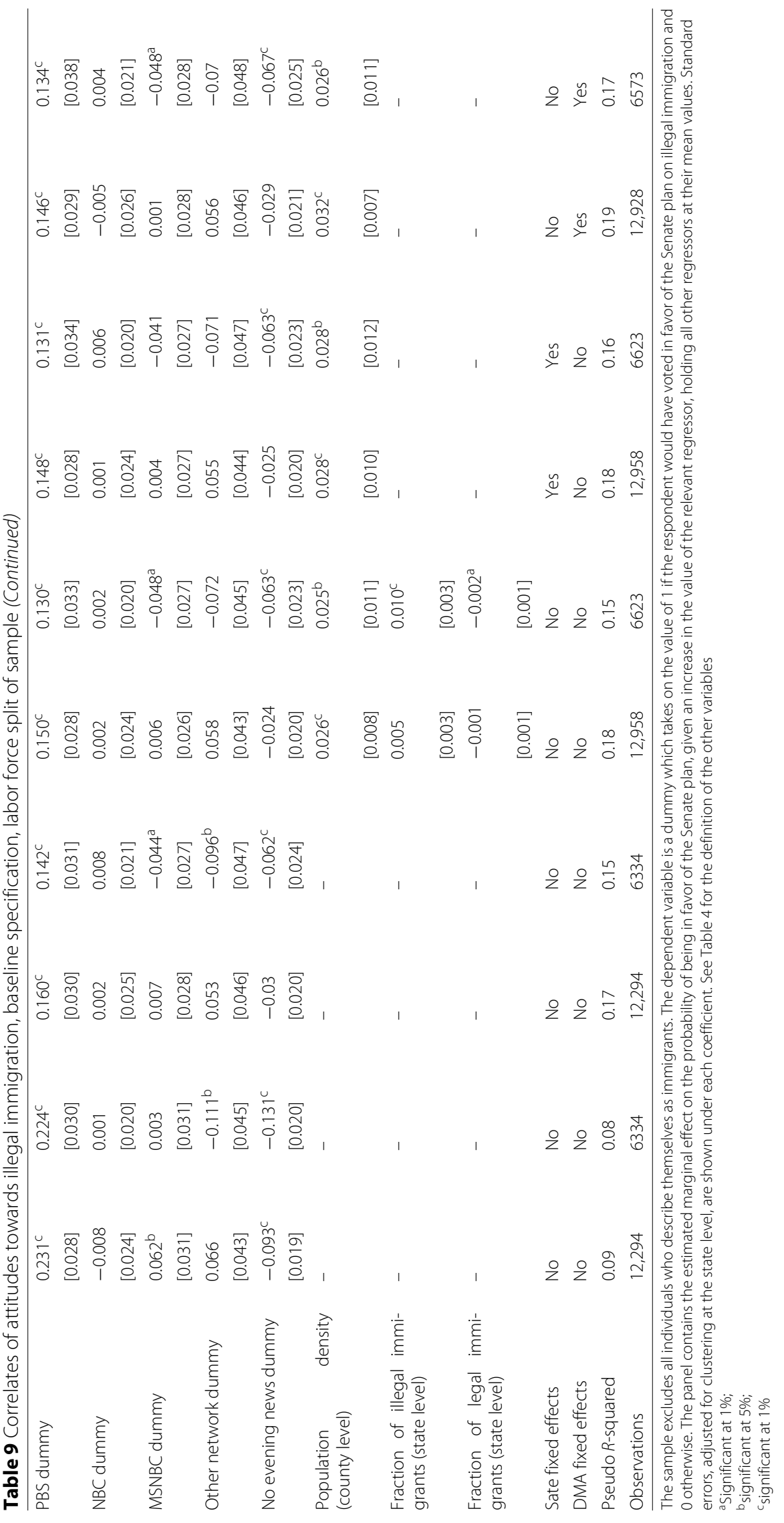




\section{Acknowledgements}

Very useful comments were provided by Jens Hainmueller, Michael Hiscox, Jim Snyder, Cecilia Testa, and seminar audiences at the TOM (Transnationality of Migrants) meeting in Bruxelles, the TOM conference in Louvain-la-Neuve, the TOM conference in Venice, the INSIDE Immigration Workshop in Barcelona, the "Dynamics of Public Opinion on Immigration in Liberal Democracies" conference at the University of Texas at Austin, the 2009 MPSA meeting in Chicago, and the 2009 APSA meeting in Toronto. Anna Maria Mayda and Riccardo Puglisi thank the European Community for financial support received through Marie Curie Fellowships within the TOM project. This paper is produced as part of the CEPR project "Politics, Economics and Global Governance: The European Dimensions" funded by the European Commission under its Seventh Framework Programme for Research (Collaborative Project), Contract no. 217559. We would like to thank the anonymous referee and the editor for the helpful comments.

Responsible editor: Denis Fougère

\section{Competing interests}

The IZA Journal of Migration is committed to the IZA Guiding Principles of Research Integrity. The authors declare that they have observed these principles.

\section{Author details}

${ }^{1}$ University of Nottingham, Nottingham, UK. ${ }^{2}$ Universita' degli Studi di Milano, Milano, Italy. ${ }^{3}$ CEPR, London, UK. ${ }^{4}$ CES-Ifo, Munich, Germany. ${ }^{5}$ CreAM, London, UK. ${ }^{6}$ LdA, Milan, Italy. ${ }^{7}$ Georgetown University, Washington, USA. ${ }^{8}$ IZA, Bonn, Germany. ${ }^{9}$ University of Pavia, Pavia, Italy.

Received: 9 December 2016 Accepted: 9 February 2017

Published online: 27 September 2017

\section{References}

Abrajano M, Singh S (2009) Examining the link between issue attitudes and news source: the case of Latinos and immigration reform. Polit Behav 31:1-30

Akdenizli B, Dionne E, Kaplan M, Rosenstiel T, Suro R (2008) A report on the media and the immigration debate. Brookings Institution, Washington

Allport GW (1954) The nature of prejudice. Addison Wesley, Reading

Ansolabehere SD, Schaffner BF (2010) Residential mobility, family structure and the cell-only population. Public Opin Q 74:244-59

Behr RH, lyengar S (1985) Television news, real-world cues, and changes in the public agenda. Public Opin Q 49:38-57

Brader T, Valentino NA, Suhay E (2008) What triggers public opposition to immigration? Anxiety, group cues, and immigration threat. Am J Polit Sci 52(4):959-78

Camarota SA (2005) The high cost of cheap labor. Mimeo, Center for Immigration Studies

Card D, Dustmann C, Preston I (2012) Immigration, wages and compositional amenities. J Eur Econ Assoc 10:78-119

Chiang CF, Knight B (2011) Media bias and influence: evidence from newspaper endorsements. Rev Econ Stud 78:795-820

Citrin J, Green DP, Muste C, Wong C (1997) Public opinion toward immigration reform: the role of economic motivations. J Polit 59:858-81

Citrin J, Sides J (2008) How large the huddled masses? The causes and consequences of public misperceptions about immigrant populations. Political Soc 56:33-56

De Philippis M (2009) Media impact on natives' attitudes towards immigration. Msc thesis, Bocconi University

DellaVigna S, Kaplan E (2007) The Fox News effect: media bias and voting. Q J Econ 122:1187-234

Dustmann C, Preston I (2007) Racial and economic factors in attitudes to immigration. BE J Econ Anal Policy 7:Article 62

Espenshade T, Hempstead K (1996) Contemporary American attitudes toward U.S. immigration. Int Migr Rev 30:535-70

Facchini G, Mayda AM (2009) Individual attitudes towards immigrants: welfare-state determinants across countries. Rev Econ Stat 91:295-314

Gentzkow MA, Shapiro JM (2010) What drives media slant? Evidence from U.S. daily newspapers. Econometrica 78(1):35-71

Gerber A, Karlan D, Bergan D (2008) Does The media matter? A field experiment measuring the effect of newspapers on voting behavior and political opinions. Am Econ J Appl Econ 1(2):32-52

Groseclose T, Milyo J (2005) A measure of media bias. Q J Econ 120:1191-237

Guisinger A (2009) Determining trade policy: do voters hold politicians accountable? Int Organ 63:533-57

Guiso L, Sapienza P, Zingales L (2003) People's opium? Religion and economic attitudes. J Monet Econ 50:225-82

Hainmueller J, Hiscox MJ (2007) Educated preferences: explaining attitudes toward immigration in Europe. Int Organ 61:399-442

Hainmueller, J, Hiscox MJ (2010) Attitudes towards highly skilled and low skilled immigration: evidence from a survey experiment. Am J Polit Sci 104:1-24

Hanson GH (2005) Why does immigration divide America? Public finance and political opposition to open borders. Mimeo, Institute for International Economics, Washington

Hanson, GH (2006) Illegal migration from Mexico to the United States. J Econ Lit 44:869-924

Hanson GH, Scheve KF, Slaughter MJ (2007) Public finance and individual preferences over globalization strategies. Econ Polit 19:1-33

Hill SJ, Lo J, Vavreck L, Zaller J (2007) The opt-in internet panel: survey mode, sampling methodology and the implicatiosn for political research. Mimeo, UCLA

Hood III MV, Morris IL (2000) Brother, can you spare a dime? Racial/ethnic context and the Anglo vote on Proposition 187. Soc Sci Q 81:180-193

lyengar S, Kinder DR (1987) News that matters: television and American opinion. Chicago University Press, Chicago 
lyengar S, Peters MD, Kinder DR (1982) Experimental demonstrations of the "not-so-minimal" consequences of television news programs. Am Polit Sci Rev 76(4):848-58

Kessler A (2001) Immigration, economic insecurity, and the 'ambivalent' American public. The Center for Comparative Immigration Studies Working Paper no. 41, San Diego

Kossoudji SA, Cobb-Clark DA (2002) Coming out of the shadows: learning about legal status and wages from the legalized population. J Labor Econ 20:598-628

Krosnick JA, Miller JM (1996) The anatomy of news media priming. In: lyengar S, Reeves R (eds). Do the Media Govern? Politicians, Voters, and Reporters in America. Sage, Thousand Oaks

Larcinese V, Puglisi R, Snyder Jr JM (2011) Partisan bias in economic news: evidence on the agenda-setting behavior of U.S. newspapers. J Public Econ 95:1178-89

Lenz GS (2009) Learning and opinion change, not priming: reconsidering the priming hypothesis. Am J Polit Sci 53(4):821-37

Lott Jr JR, Hassett KA (2004) Is newspaper coverage of economic events politically biased? Working paper, American Enterprise Institute. Available at. http://ssrn.com/abstract=588453

Mayda AM (2006) Who is against immigration? A cross-country investigation of individual attitudes toward immigrants. Rev Econ Stat 88:510-30

McCombs ME (2002) The agenda-setting role of the mass media in the shaping of public opinion. Technical report, London School of Economics. Paper presented at Mass Media Economics 2002 Conference

McCombs ME, Shaw DL (1972) The agenda-setting function of mass media. Public Opin Q 36:176-87

Newton LY (2000) Why some Latinos supported proposition 187: testing economic threat and cultural identity hypothesis. Soc Sci Q 81:194-206

O'Rourke KH, Sinnott R (2006) The determinants of individual attitudes towards immigration. Eur J Polit Econ 22:838-61

Orrenius PM, Zavodny M (2007) Does immigration affect wages? A look at occupational level evidence. Labour Econ 14:757-73

Ortega F, Polavieja JG (2012) Labor-market exposure as a determinant of attitudes toward immigration. Labour Econ 19:298-311

Passel JS (2005) Unauthorized migrants: numbers and characteristics. Mimeo, Pew Hispanic Center

Puglisi R (2011) Being the New York Times: the political behaviour of a newspaper. BE J Econ Anal Policy 11:Article 20. Contributions

Puglisi R, Snyder Jr JM (2011) Newspaper coverage of political scandals. J Polit 73:931-50

Scheve KF, Slaughter MJ (2001) Labor market competition and individual preferences over immigration policy. Rev Econ Stat 83:133-45

Tam WK, Cain BE (2001) Asian Americans as the median voters: attitudes and voting patterns on ballot initiatives. In: Chang G (ed). Asian American and Politics: Perspectives, experiences, prospects. Woodrow Wilson Center Press, Washington

Valentino NA, Hutchings VL, White I (2002) Cues that matter: how political ads prime racial attitudes during campaigns. Am Polit Sci Rev 96(1):75-90

Weaver DH (2007) Thoughts on agenda setting, framing, and priming. J Commun 57:142-7

Zaller JR (1992) The Nature and Origins of Mass Opinion. Cambridge University Press, Cambridge

\section{Submit your manuscript to a SpringerOpen ${ }^{\circ}$ journal and benefit from:}

$\rightarrow$ Convenient online submission

$\rightarrow$ Rigorous peer review

- Immediate publication on acceptance

- Open access: articles freely available online

- High visibility within the field

- Retaining the copyright to your article

Submit your next manuscript at $\boldsymbol{\triangleright}$ springeropen.com 